\title{
Molecular Biomarkers in the Clinical Management of Prostate Cancer
}

\author{
Aaron M. Udager ${ }^{1}$ and Scott A. Tomlins $\mathbf{s}^{1,2,3,4}$ \\ ${ }^{1}$ Department of Pathology, University of Michigan Medical School, Ann Arbor, Michigan 48109-5054 \\ ${ }^{2}$ Department of Urology, University of Michigan Medical School, Ann Arbor, Michigan 48109-5948 \\ ${ }^{3}$ Comprehensive Cancer Center, Michigan Medicine, Ann Arbor, Michigan 48109-0944 \\ ${ }^{4}$ Michigan Center for Translational Pathology, Ann Arbor, Michigan 48109-5940 \\ Correspondence: tomlinss@umich.edu
}

\begin{abstract}
Prostate cancer, one of the most common noncutaneous malignancies in men, is a heterogeneous disease with variable clinical outcome. Although the majority of patients harbor indolent tumors that are essentially cured by local therapy, subsets of patients present with aggressive disease or recur/progress after primary treatment. With this in mind, modern clinical approaches to prostate cancer emphasize the need to reduce overdiagnosis and overtreatment via personalized medicine. Advances in our understanding of prostate cancer pathogenesis, coupled with recent technologic innovations, have facilitated the development and validation of numerous molecular biomarkers, representing a range of macromolecules assayed from a variety of patient sample types, to help guide the clinical management of prostate cancer, including early detection, diagnosis, prognostication, and targeted therapeutic selection. Herein, we review the current state of the art regarding prostate cancer molecular biomarkers, emphasizing those with demonstrated utility in clinical practice.
\end{abstract}

Erom early detection through diagnosis and F treatment, the clinical management of prostate cancer is a multistep process that necessitates a collaborative, multidisciplinary approach, and, at each step, established and emerging molecular biomarkers are available to help guide clinicians. Although prostate cancer is the most common noncutaneous malignancy in American men, for the majority of patients, it is an indolent disease with excellent long-term survival rates (Thompson et al. 2013; Siegel et al. 2017). Thus, recent clinical paradigms have focused on decreasing the usage of prostate biop- sies in clinically asymptomatic men and deferring definitive treatment of men with low-grade tumors until the disease progresses to a more aggressive form (i.e., active surveillance) (Shieh et al. 2016; Tosoian et al. 2016); these efforts aim to reduce the identification (overdiagnosis) and overtreatment of patients with indolent disease, respectively. On the other hand, patients who either present with or subsequently develop metastatic prostate cancer are not typically treated with curative intent, and few therapeutic options are available to relieve clinical symptoms (i.e., bone pain, spinal cord compression, hyper-

Editors: Michael M. Shen and Mark A. Rubin

Additional Perspectives on Prostate Cancer available at www.perspectivesinmedicine.org

Copyright (C) 2018 Cold Spring Harbor Laboratory Press; all rights reserved; doi: 10.1101/cshperspect.a030601

Cite this article as Cold Spring Harb Perspect Med 2018;8:a030601 
calcemia, etc.) related to increasing tumor burden. Thus, there are clear opportunities for improvement in prostate cancer early detection, diagnosis, and prognostication, as well as a potential role for targeted therapeutic approaches in patients with advanced disease.

Advances in our understanding of the oncogenesis of prostate cancer, as well as recent technological innovations, have spurred the development of numerous proposed biomarkers, which represent a broad spectrum of macromolecules, including DNA, RNA, and protein, and are assayed in a variety of patient samples, including blood, urine, and tissue. Despite this multitude of potential biomarkers, however, relatively few have been successfully translated to clinical practice, in part because the clinical utility of a given biomarker depends on its estimated net benefit over existing clinicopathologic models. For example, histopathologic review of prostate core biopsy and radical prostatectomy material remains a fundamental aspect of prostate cancer clinical management; in particular, histologic grading via assignment of a Gleason score (GS) and clinical and/or pathologic staging via the American Joint Committee on Cancer (AJCC) tumor/node/metastasis (TNM) system are effective for risk-stratifying patients for clinical decision-making purposes. Thus, for a proposed new prostate cancer molecular biomarker, the most important issue for clinical translation is whether its inclusion significantly improves the performance of existing optimized models that incorporate routinely available clinicopathologic information. Importantly, this is different than just showing statistically significant independence as a predictive/prognostic factor in a multivariate model and, correspondingly, is a much higher bar for a potential biomarker to clear (Kattan 2003). Likewise, molecular biomarkers much show clear improvement over clinicopathological parameter improvement, which likely can be implemented with little to no cost. For example, Sauter et al. (2016) recently showed through assessment of more than 10,000 cases that, although the GS is a strong prognostic parameter for predicting biochemical recurrence, further stratification of GS 7 tumors by $\%$ pattern 4 markedly improves the prognostic performance. Hence, to truly assess the benefit of molecular prognostic biomarkers, such biomarkers should be added to models including quantitative Gleason scoring to truly assess their ability to improve on optimized clinicopathological models. With this in mind, this article focuses on current and emerging biomarkers likely to be used in the clinical management of prostate cancer.

\section{EARLY DETECTION}

Current early detection programs for prostate cancer have two main goals: (1) identify asymptomatic men with prostate cancer for prostate core biopsy, and (2) determine which men with prostate cancer would benefit from definitive treatment. Indeed, for the majority of patients, these are the central issues in the evaluation and clinical management of prostate cancer and, as such, much of the effort in the development, validation, and application of prostate cancer molecular biomarkers has been focused on improving these clinical objectives.

Serum total prostate-specific antigen (PSA) is the canonical prostate cancer biomarker, and despite recent debate about its role in early detection programs, it remains the most commonly used biomarker in the clinical management of prostate cancer (Fig. 1A). PSA, which is encoded by KLK3 and regulated by androgen receptor signaling, is a highly prostate-specific protein macromolecule that is expressed predominantly in prostatic tissue, serum, and seminal fluid (Balk et al. 2003; Lilja et al. 2008; Thorek et al. 2013). Similar to other serine proteases in the kallikrein family, PSA is translated as a preproenzyme (preproPSA), which undergoes posttranslational processing into the proenzyme (proPSA) and final active forms via trypsin-like proteases (including human kallikrein 2 [hK2], another prostatic-specific member of the kallikrein family encoded by KLK2), although a subset of proPSA molecules are instead processed into catalytically inactive forms (e.g., [-2]proPSA). In serum, PSA molecules circulate either in the active form complexed to protease inhibitors (e.g., $\alpha-1$ antitrypsin) or uncomplexed as one of several inactive forms (col- 
A
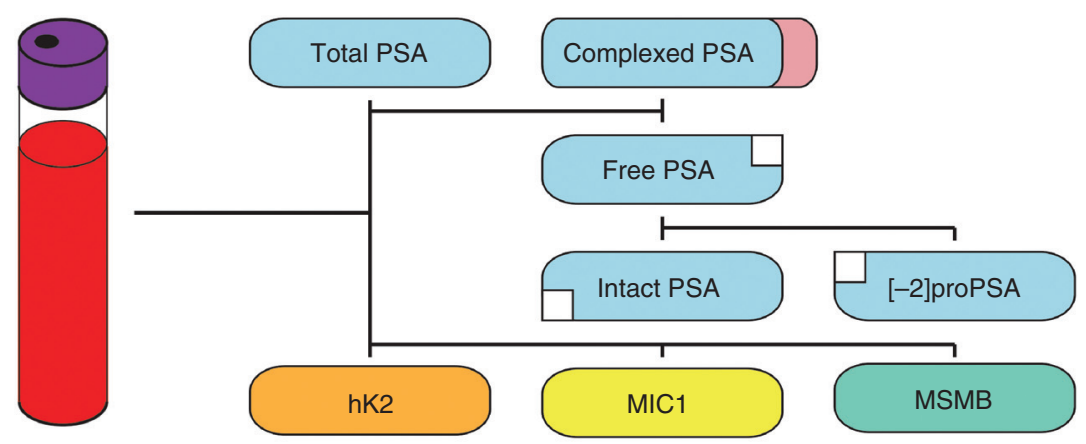

$\%$ Free PSA:

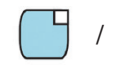

phi:

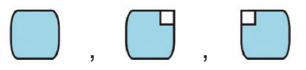

4K panel:
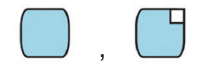

STHLM3:
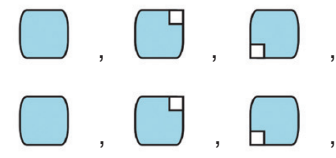

B

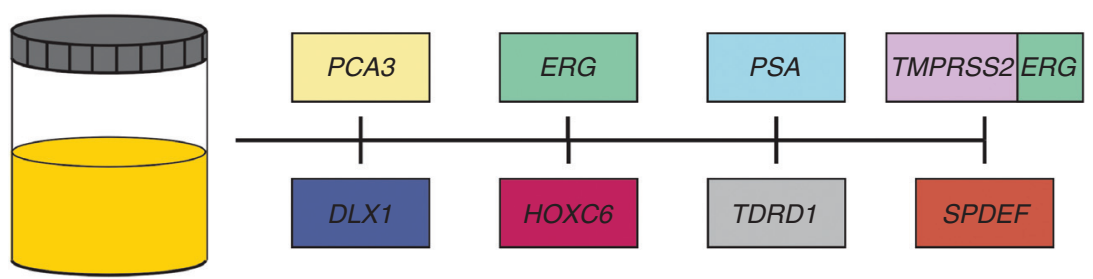

Progensa PCA3:

MiPS:
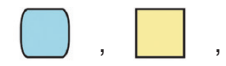

Leyten et al:
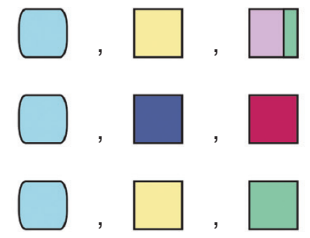

EPI:
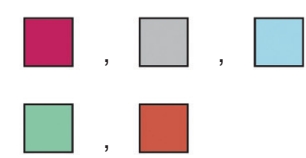

Figure 1. Molecular biomarkers for early detection of prostate cancer. (A) Serum-based molecular biomarkers for early detection of prostate cancer include total prostate-specific antigen (PSA), free PSA, intact PSA, [-2]proPSA, human kallikrein 2 (hK2), MIC1, and MSMB. \% free PSA is calculated as the percentage of free PSA (including intact PSA and [-2]proPSA) compared with total PSA (which includes complexed PSA). The Prostate Health Index (phi) test combines assessment of total PSA, free PSA, and [-2]proPSA. The 4K panel measures total PSA, free PSA, intact PSA, and hK2. The STHLM3 model includes total PSA, free PSA, intact PSA, hK2, MIC1, and MSMB. (B) Urine-based molecular biomarkers for early detection of prostate cancer include PCA3, ERG, PSA, TMPRSS2:ERG, DLX1, HOXC6, TDRD1, and SPDEF. The Food and Drug Administration (FDA)-approved Progensa PCA3 assay only measures PCA3, whereas the Mi-Prostate Score (MiPS) also includes assessment of serum total PSA and urine TMPRSS2:ERG. In addition to serum total PSA, the model proposed by Leyten et al. measures urine DLX1, HOXC6, and TDRD1 (which are normalized to urine PSA) (Leyten et al. 2015). The ExoDx Prostate IntelliScore (EPI) combines serum total PSA with urine PCA3 and ERG (which are normalized to urine SPDEF). 
lectively known as "free PSA"); these free PSA molecules include both intact and nicked or multichain forms. Thus, serum total PSA represents the sum of complexed active PSA and complexed free PSA molecules.

For many patients who undergo biomarker testing for prostate cancer, serum total PSA is the only value assayed. In general, increasing serum total PSA is associated with an increasing likelihood of prostate cancer and risk of clinically significant disease (GS $\geq 7$ ); however, serum total PSA is also positively correlated with increasing age and prostate gland volume (i.e., benign prostatic hypertrophy), and serum total PSA may also be elevated in patients with other benign conditions, such as prostatitis (Balk et al. 2003; Lilja et al. 2008; Thorek et al. 2013). Therefore, in clinically asymptomatic men undergoing early detection for prostate cancer, an isolated elevated serum total PSA value needs to be interpreted with caution, and it is now recommended that, before initiating a PSA-based early detection program for prostate cancer, an informed discussion with the patient regarding the probability of prostate cancer, risk of clinically significant disease, available treatment options, and long-term clinical prognosis should be undertaken (Mottet et al. 2017).

There is no universally accepted lower threshold for serum total PSA in prostate cancer early detection programs, and most modern programs use age-adjusted values based on distributions in presumed cancer-free populations (Mottet et al. 2017). As indicated above, however, with increasing levels of serum total PSA, there is a higher likelihood of prostate cancer and risk of clinically significant disease (Balk et al. 2003; Lilja et al. 2008; Thorek et al. 2013). For example, for the majority of patients with serum total PSA $\geq 10 \mathrm{ng} / \mathrm{mL}$, no additional biomarker tests are typically necessary for risk-stratification within prostate cancer early detection programs (Mottet et al. 2017). Indeed, patients with serum total PSA $\geq 10 \mathrm{ng} / \mathrm{mL}$ and a negative prostate biopsy typically undergo repeat biopsy and/or close clinical follow-up to exclude clinically significant prostate cancer; similarly, patients with serum total PSA $\geq 20 \mathrm{ng} / \mathrm{mL}$ have an increased risk of high-grade ( $G S \geq 8$ ) prostate cancer and, regardless of the biopsy results, may undergo radiographic workup (i.e., bone scan) to evaluate for possible metastatic disease (Mottet et al. 2017). On the other hand, for patients with serum total PSA $<10 \mathrm{ng} / \mathrm{mL}$, the false positive rate is high (with a corresponding low positive predictive value for prostate cancer), and many of the detected tumors are relatively low grade (GS6) (Balk et al. 2003; Lilja et al. 2008; Thorek et al. 2013).

To augment the clinical utility of serum total PSA, several additional PSA-based metrics have been devised, including age- and race-adjusted PSA cutoffs, PSA trajectory, and PSA density (utilizing an estimated prostate gland volume from transrectal ultrasonagraphy); although, in general, these measurements only incrementally add to the positive predictive value for prostate cancer in patients with serum total PSA $<10 \mathrm{ng} /$ mL (Balk et al. 2003; Lilja et al. 2008; Thorek et al. 2013). Thus, additional serum-based protein biomarkers, including serum free PSA, intact PSA, [-2]proPSA, and hK2, have been developed to improve prostate cancer detection and risk stratification in these patients (Fig. 1A) (Thorek et al. 2013). Indeed, increasing serum free PSA, intact PSA, [-2]proPSA, and hK2 are all independently associated with a higher risk of prostate cancer in clinically asymptomatic men, and higher serum hK2 levels are correlated with an increased likelihood of clinically significant disease (Recker et al. 2000; Mikolajczyk et al. 2001; Steuber et al. 2002, 2007). In addition to absolute serum levels, the serum free-to-total PSA and intact-to-free PSA ratios are associated with an increased risk of prostate cancer in patients with serum total PSA $<10 \mathrm{ng} / \mathrm{mL}$ (Bjork et al. 1996; Steuber et al. 2002).

Two combinatorial serum protein biomarker assays have recently been validated for prostate cancer early detection programs (in particular, patients with serum total PSA $<10 \mathrm{ng} / \mathrm{mL}$ ): the Prostate Health Index (phi) test and four kallikrein (4K) panel (Fig. 1A). The phi test combines serum total PSA, free PSA, and [-2]proPSA into a single score, and an increasing phi score is associated with increased likelihood of prostate cancer and risk of clinically significant disease (Loeb et al. 
2014; de la Calle et al. 2015; Tosoian et al. 2017a b). The $4 \mathrm{~K}$ panel, on the other hand, combines serum total PSA, free PSA, intact PSA, and hK2 into a single score, and an increasing $4 \mathrm{~K}$ score is associated with a higher risk of prostate cancer and likelihood of clinically significant disease (Vickers et al. 2008, 2010a,b, 2011; Loeb et al. 2014; Parekh et al. 2014; Bryant et al. 2015; Stattin et al. 2015). Importantly, both the phi test and $4 \mathrm{~K}$ panel outperform their individual components (including total PSA), although they show similar clinical value when compared with one another (Nordström et al. 2014). Likewise, Gronberg et al. (2015) showed the additive performance of the serum-based protein biomarkers MSMB, MIC1, free PSA, intact PSA, and hK2 to serum total PSA for predicting clinically significant prostate cancer in a large prospective Swedish early detection cohort (Fig. 1A).

In addition to new serum-based protein biomarkers, several novel urine-based RNA biomarkers have been developed for prostate cancer early detection programs, including prostate cancer-specific molecules such as the long noncoding RNA (lncRNA) PCA3 and TMPRSS2: $E R G$ gene fusion transcripts (Fig. 1B). Increasing urine $P C A 3$ scores are associated with an increased likelihood of prostate cancer in clinically asymptomatic men, and this association is independent of serum total PSA (Bussemakers et al. 1999; de Kok et al. 2002; Hessels et al. 2003, 2007; Ankerst et al. 2008; Deras et al. 2008; Chun et al. 2009; Auprich et al. 2010). Thus, urine PCA3, assessed by the Progensa PCA3 assay, has been approved by the Food and Drug Administration (FDA) for prostate cancer risk assessment in patients with a prior negative prostate core biopsy who are being considered for a repeat biopsy; for these patients, a high $P C A 3$ score indicates a high risk of clinically occult prostate cancer (and, therefore, need for repeat biopsy), whereas a low $P C A 3$ score signifies a low risk of prostate cancer (for which repeat biopsy can be deferred). Similar to urine PCA3, urine TMPRSS2:ERG shows high specificity for prostate cancer (Laxman et al. 2006, 2008); however, because the TMPRSS2:ERG gene fusion is only identified in approximately
$40 \%-50 \%$ of prostate cancers (Tomlins et al. 2005; Mehra et al. 2007), its use as a stand-alone assay is limited owing to lack of sufficient sensitivity. A combinatorial assay (Mi-Prostate Score [MiPS]) that includes serum total PSA, urine PCA3, and urine TMPRSS2:ERG, however, shows incremental improvement in detecting both prostate cancer and clinically significant disease in patients with serum total PSA $<10 \mathrm{ng} / \mathrm{mL}$ compared with serum total PSA alone (Fig. 1B) (Tomlins et al. 2011, 2016; Salami et al. 2013; Merdan et al. 2015; Sanda et al. 2017). More recently, assessment of DLX1, HOXC6, and TDRD1 urine messenger RNA (mRNA) transcripts, normalized to PSA, has been shown to improve detection of clinically significant prostate cancer when combined with serum total PSA (Leyten et al. 2015; Van Neste et al. 2016); likewise, an assay that detects $P C A 3$ and $E R G$ urine transcripts from non-DRE collected whole urine exosomes (normalized to SPDEF expression) to detect clinically significant prostate cancer when combined with serum total PSA has also recently been validated (Fig. 1B) (McKiernan et al. 2016).

Finally, although our understanding of germline variants associated with an increased prostate cancer risk is incomplete, it is clear that subsets of patients with germline mutations in specific genes (e.g., HOXB13, BRCA1, BRCA2) are at an increased risk of developing prostate cancer (Castro and Eeles 2012; Ewing et al. 2012), and germline mutations in DNA repair genes (i.e., BRCA1, BRCA2, ATM, CHEK2, $R A D 51 D$, and $P A L B 2)$ are enriched in prostate cancer patients with metastatic disease (Pritchard et al. 2016). In addition, a number of single nucleotide polymorphisms (SNPs) identified via genome-wide association studies (GWAS) are associated with an increased prostate cancer risk (Al Olama et al. 2009, 2014; Eeles et al. 2009), although the effect size of these SNPs (either alone or in combination) is relatively modest (Amin Al Olama et al. 2015; Pashayan et al. 2015). Regardless, clinical assessment of these cancer-susceptibility genes and/or disease-associated SNPs may be useful for riskstratifying clinically asymptomatic men in prostate cancer early detection programs. 
A.M. Udager and S.A. Tomlins

\section{DIAGNOSIS}

Although the diagnosis of prostate cancer remains firmly rooted in histopathologic review of prostate core biopsy tissue, several tissue-based molecular biomarkers have recently emerged as ancillary tools for pathologists and/or clinicians. For the vast majority of patients, recognition of prostate cancer by surgical pathologists utilizing routine hematoxylin and eosin (H\&E) slides of prostate biopsy tissue and established morphologic criteria is straightforward. Nonetheless, there are several specific instances in which ancillary tests such as immunohistochemistry (IHC) or in situ hybridization (ISH) may be helpful. Occasionally, foci of atypical prostatic glands suspicious for, but not diagnostic of small cell prostate cancer are identified in prostate core biopsies; these foci are typically termed atypical small acinar proliferation (ASAP) (Iczkowski et al. 1997). IHC using PIN-4 cocktail (composed of basal cell markers [p63 and high- molecular-weight cytokeratins] and the cancerassociated protein biomarker AMACR and the prostate cancer-specific protein biomarker ERG (corresponding to the expressed translated product of the TMPRSS2:ERG gene fusion) are useful in the clinical evaluation of ASAP foci and may help to make a definitive diagnosis of prostate cancer in a subset of cases (Fig. 2) (Jiang et al. 2005; Park et al. 2010; He et al. 2011; Tomlins et al. 2012). An ASAP focus that lacks basal cell marker staining and expresses AMACR and ERG is essentially diagnostic of prostate cancer.

Other scenarios in which ancillary tests may be helpful in prostate cancer diagnosis include evaluation of intraductal carcinoma of the prostate (IDC-P) and high-grade neuroendocrine prostate carcinoma ([NEPC], i.e., "small cell carcinoma of the prostate"). Recent molecular data have shed new insight on IDC-P, an aggressive form of prostate cancer that spreads in situ within the existing ducts and acini of the pros-

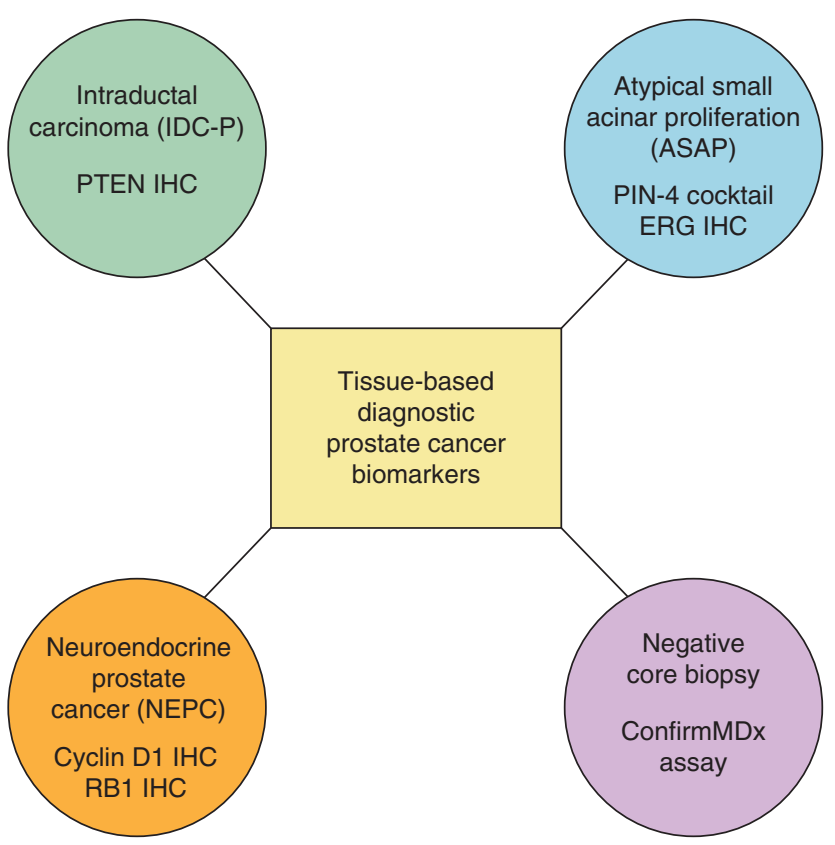

Figure 2. Molecular biomarkers for diagnosis of prostate cancer. Tissue-based molecular biomarkers for prostate cancer diagnosis include PTEN immunohistochemistry (IHC) for intraductal carcinoma of the prostate (IDC-P), PIN-4 cocktail and ERG IHC for atypical small acinar proliferation (ASAP), RB1 and cyclin D1 IHC for neuroendocrine prostate cancer (NEPC), and a polymerase chain reaction (PCR)-based methylation assay (ConfirmMDx) for negative core biopsies. 
tate gland (Magers et al. 2015; Chua et al. 2017) Unlike its histopathologic mimic high-grade intraepithelial neoplasia-a benign, nonobligate precursor to invasive prostate cancer-IDC-P shows frequent PTEN gene alterations, which can be detected as loss of PTEN protein by IHC (Fig. 2) (Lotan et al. 2013; Morais et al. 2015; Hickman et al. 2017). Similarly, although the diagnosis of NEPC can typically be made on histomorphologic grounds (with or without corresponding IHC for neuroendocrine markers) (Epstein et al. 2014), recent studies have identified recurrent $R B 1$ gene alterations in NEPC (Tan et al. 2014; Beltran et al. 2016), and, thus, IHC to detect dysregulated retinoblastoma pathway proteins (including RB1 and cyclin D1) may be helpful diagnostically in cases without neuroendocrine marker staining (Fig. 2) (Tan et al. 2014; Tsai et al. 2015). In addition, NEPC may be difficult to distinguish histopathologically from small cell carcinoma of the urinary tract (i.e., urinary bladder or urethra) or metastatic small cell carcinoma from other organs (i.e., lung). In these cases, fluorescent in situ hybridization (FISH) to detect ERG gene rearrangements may be helpful to confirm prostatic origin of the tumor, as ERG gene rearrangements are highly specific for prostate cancer (although, as previously discussed, the incidence of TMPRSS2:ERG gene fusions in prostate cancer limits the sensitivity of this assay, and a negative result does not exclude a primary prostatic tumor) (Han et al. 2009; Lotan et al. 2011a; Williamson et al. 2011; Schelling et al. 2013). Likewise, recurrent mutations in the promoter of TERT are much more frequent in urothelial carcinomas (or bladder small cell carcinoma) compared with prostatic adenocarcinoma (or prostatic NEPC) and, hence, may also have diagnostic utility for determining site of origin (Huang et al. 2013; Killela et al. 2013; Zheng et al. 2014).

Finally, a tissue-based molecular biomarker assay has been recently developed to help prostate cancer risk assessment in men with a prior negative prostate core biopsy who are being considered for a repeat biopsy. The ConfirmMDx assay uses methylation-specific polymerase chain reaction (PCR) to detect methylation at multiple gene loci, including APC and GSTP1, which are more frequently methylated in prostate cancer than benign prostatic tissue (Fig. 2) (Enokida et al. 2005; Trock et al. 2012; Partin et al. 2014). This assay has a very high negative predictive value for prostate cancer, as the absence of hypermethylated gene loci in tissue from the previous negative biopsy is strongly correlated with a lack of prostate cancer on repeat biopsy.

\section{PROGNOSIS}

Current prostate cancer prognostication is based on readily available clinical information (i.e., age, serum total PSA, etc.) and histopathologic review of either prostate core biopsy or radical prostatectomy tissue (i.e., GS, clinical or pathologic stage, etc.). At the time of prostate core biopsy, the outcome of interest for clinicians is typically the likelihood that a patient harbors clinically significant disease (and, therefore, requires definitive treatment) but may also include an assessment of overall cancer-specific mortality; on the other hand, at the time of radical prostatectomy, the outcomes of interest are usually the risk of early biochemical recurrence (which may necessitate adjuvant therapy) and overall cancer-specific mortality. For many patients, current clinicopathologic variables provide adequate risk stratification; however, a subset of patients with presumed low-risk disease will be undertreated, whereas a group of patients with presumed high-risk disease with be overtreated. With this in mind, a multitude of tissuebased molecular biomarkers have been proposed to help refine these clinical prognostications; despite these efforts, however, only a few single-gene and multigene assays have emerged as likely to be clinically useful.

PTEN alterations, including focal deletion, somatic mutation, and promoter hypermethylation, are among the most frequent genomic alterations in prostate cancer (Phin et al. 2013; Wise et al. 2017), and loss of PTEN function through combinatorial inactivation of the PTEN gene locus can be detected via FISH or IHC (Fig. 3) (Verhagen et al. 2006; Yoshimoto et al. 2006; Lotan et al. 2011b, 2016; Sathyanar- 
A.M. Udager and S.A. Tomlins

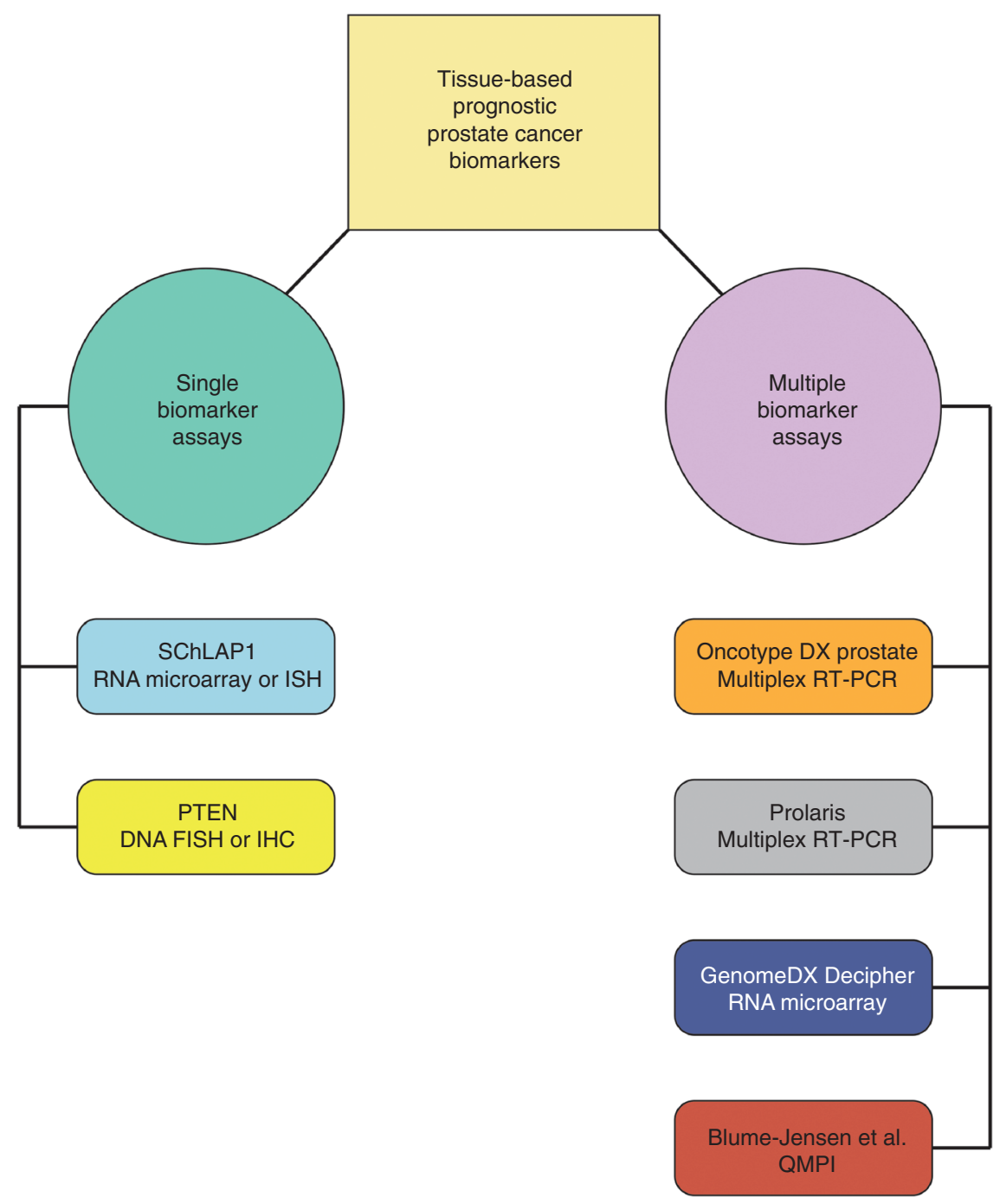

Figure 3. Molecular biomarkers for prognostication of prostate cancer. Tissue-based molecular biomarkers for prostate cancer prognostication include single and multiple biomarker assays. Single biomarker assays with clinical utility include SChLAP1 RNA microarray or in situ hybridization (ISH) and PTEN DNA fluorescent in situ hybridization (FISH) or immunohistochemistry (IHC). Multiple biomarker assays with clinical utility include multiplex reverse transcription polymerase chain reaction (RT-PCR) assays (Oncotype Dx Prostate and Prolaris), RNA microarray (GenomeDx Decipher), and quantitative multiplex proteomics imaging ([QMPI] as reported by Blume-Jensen et al. 2015).

ayana et al. 2015; Picanco-Albuquerque et al. 2016). Loss of PTEN function in prostate cancer at the time of prostate core biopsy is associated with GS upgrading and locally advanced disease at the time of radical prostatectomy as well as decreased recurrence-free survival after definitive treatment (Lotan et al. 2015; Picanco-
Albuquerque et al. 2016; Trock et al. 2016; Guedes et al. 2017). Similarly, loss of PTEN function in prostate cancer at the time of radical prostatectomy is associated with high-risk disease and poor clinical outcome (i.e., early biochemical recurrence, metastasis, prostate cancer-specific mortality, etc.) (Lotan et al. 2011b; 
Krohn et al. 2012; Ahearn et al. 2016). Finally, loss of PTEN function is associated with prostate cancer-specific mortality in low-risk patients managed conservatively with transurethral resection of the prostate (TURP) alone (Cuzick et al. 2013).

lncRNAs are a unique class of RNA molecules with increasingly recognized roles in tumor biology (Prensner and Chinnaiyan 2011; Iyer et al. 2015). Recent transcriptomic profiling studies have identified a number of prostate cancer-specific lncRNAs, including SChLAP1, which shows outlier expression in a subset of prostate cancers and is strongly associated with aggressive, lethal disease (Fig. 3) (Prensner et al. 2011, 2013, 2014b). Although several lncRNAs are likely to have clinical value for prostate cancer prognostication, SChLAP1 is currently the best characterized, and its prognostic utility has been validated across a variety of platforms (i.e., RNA microarray, RNA ISH, etc.) and independent patient cohorts (Prensner et al. 2013, 2014b; Mehra et al. 2014, 2016; Bottcher et al. 2015). Indeed, high SChLAP1 expression is associated with high-grade and locally advanced disease at the time of radical prostatectomy, early biochemical recurrence and metastasis after radical prostatectomy, and prostate cancer-specific mortality, and, importantly, it identifies a subset of patients with presumed low-risk disease that have a very poor clinical outcome (Prensner et al. 2013, 2014b; Mehra et al. 2014, 2016; Bottcher et al. 2015).

Despite the relative dearth of single gene prognostic assays, a number of recent multigene assays have been developed for prostate cancer prognostication, including Oncotype DX Prostate, Prolaris, and GenomeDx Decipher (Fig. 3). Oncotype DX Prostate is a multiplex reverse transcription polymerase chain reaction (RTPCR)-based assay for use with prostate core biopsy material that measures expression of 12 prostate cancer-related genes and five reference genes to generate the genomic prostate score (GPS) (Knezevic et al. 2013). In otherwise lowrisk patients, a high GPS is associated with highrisk disease at the time of radical prostatectomy and an increased risk of biochemical recurrence after definitive treatment (Cullen et al. 2014;
Klein et al. 2014; Brand et al. 2016). Similar to Oncotype DX Prostate, Prolaris is a multiplex RT-PCR-based gene-expression assay; however, the Polaris test integrates expression of 31 genes involved in cell-cycle progression (CCP) to generate a CCP score and is used for core biopsy, radical prostatectomy, or TURP material $(\mathrm{Cu}-$ zick et al. 2011). In multiple, large independent cohorts, a high CCP score is associated with increased risk of biochemical recurrence after radical prostatectomy and prostate cancer-specific mortality in low-risk patients managed conservatively with TURP alone (Cuzick et al. 2011, 2012; Cooperberg et al. 2013; Bishoff et al. 2014; Sommariva et al. 2014; Tosoian et al. 2017c). In contrast to Oncotype DX Prostate and Prolaris, GenomeDx Decipher is an RNA microarray-based test for use with core biopsy or radical prostatectomy material that assays expression of 22 RNA molecules to calculate a genomic classifier (GC) score (Erho et al. 2013). In intermediate- and high-risk prostate cancer patients, a high GC score is associated with metastatic progression and cancer-specific mortality after radical prostatectomy and may identify patients who would benefit from early adjuvant therapy (Erho et al. 2013; Karnes et al. 2013, 2017; Cooperberg et al. 2014; Den et al. 2015; Klein et al. 2015; Ross et al. 2016; Dalela et al. 2017; Spratt et al. 2017). Furthermore, a high GC score at the time of prostate biopsy is associated with increased metastatic progression and cancer-specific mortality after primary therapy (Klein et al. 2016; Nguyen et al. 2017) and may predict metastasis after salvage radiation for recurrent prostate cancer after radical prostatectomy (Freedland et al. 2016).

Finally, an eight-biomarker multiplex immunofluorescence (IF)-based assay has been recently validated for prostate cancer prognostication, using prostate core biopsy material. This assay uses quantitative multiplex proteomics imaging (QMPI) to make automated, quantitative measurements of each of the eight biomarkers and generate a biomarker risk score (Fig. 3) (Blume-Jensen et al. 2015). A high biomarker risk score is associated with both clinically significant disease (GS $\geq 7$ vs. GS6) and high-risk disease at radical prostatectomy. 
A.M. Udager and S.A. Tomlins

\section{TARGETED THERAPEUTICS}

The current treatment paradigms for advanced/ metastatic prostate cancer predominantly involve targeting the androgen signaling pathway but may include other types of conventional chemotherapy for patients with aggressive disease (i.e., NEPC). The theory underlying hormonal therapy for advanced prostate cancer is that, in the majority of patients, activation of the androgen signaling pathway drives growth of cancer cells, and thus these tumors are "addicted" to androgen receptor signaling for their survival (Antonarakis et al. 2016). Prostate cancer treated with hormonal therapy, however, may develop resistance via several mechanisms, including amplification, mutation, and/or differential splicing of the androgen receptor gene, leading to the development of castrationresistant prostate cancer (CRPC) (Watson et al. 2015; Antonarakis et al. 2016). As such, molecular analysis of the androgen receptor gene may have clinical significance for monitoring the de- velopment of resistance to hormonal therapy (Fig. 4). In particular, the detection of the V7 androgen receptor splice variant (either in tissue, circulating tumor cells, or cell-free nucleic acids) is associated with decreased response to specific types of hormonal therapy and poor progression-free and overall survival (Antonarakis et al. 2014, 2015; Onstenk et al. 2015; Scher et al. 2016, 2017; Del Re et al. 2017). In addition, secondary to sustained targeting of the androgen signaling pathway with hormonal therapy, a subset of patients with advanced prostate cancer will develop androgen-insensitive prostate cancer (AIPC) via acquired alterations in TP53, RB1, and/or PTEN (Watson et al. 2015). For these patients, cancer cells are no longer dependent on or sensitive to inhibition of the androgen receptor signaling pathway, and many of these tumors show overlapping clinical and pathologic features with NEPC.

Aside from hormonal therapy, there is currently very limited targeted therapeutic selection for the treatment of advanced prostate cancer,

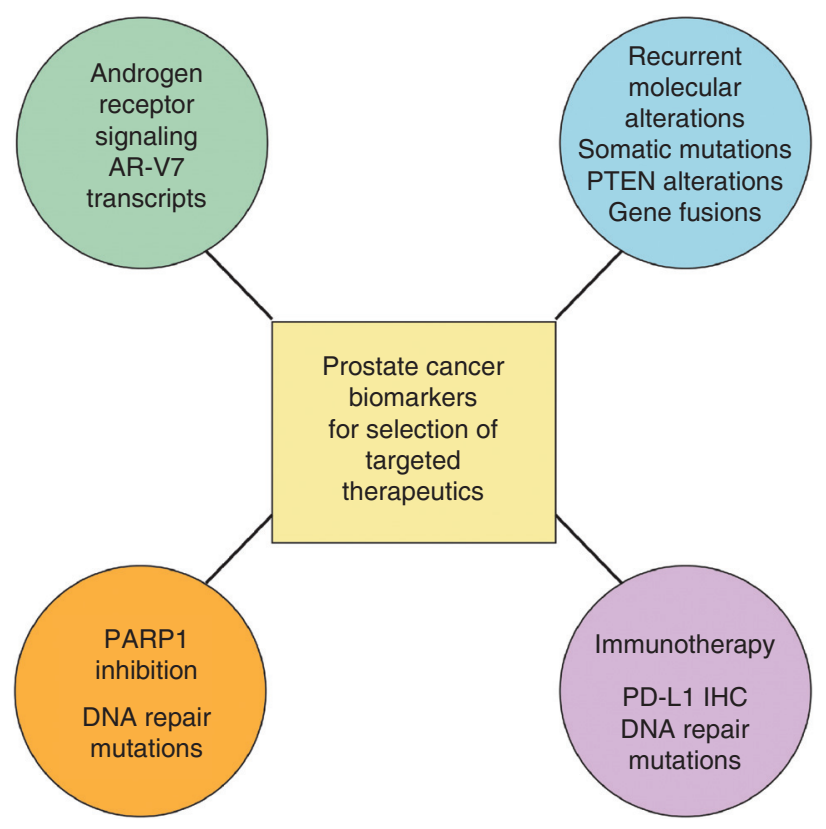

Figure 4. Molecular biomarkers for selection of targeted therapeutics for prostate cancer. Molecular biomarkers for prostate cancer-targeted therapeutics include AR-V7 transcripts (androgen receptor signaling); somatic mutations, PTEN alterations, and gene fusions (recurrent molecular alterations); DNA repair mutations (PARP1 inhibition and immunotherapy); and PD-L1 immunohistochemistry (IHC) (immunotherapy). 
although several recurrent molecular alterations present attractive targets for future therapeutic options (Fig. 4). PTEN alterations are among the most common recurrent genomic alterations in prostate cancer, and loss of PTEN activity leads to dysregulation of the PI3K signaling pathway; thus, emerging small-molecule PI3K inhibitors may have therapeutic relevance in advanced tumors with PTEN alterations (Phin et al. 2013; Wise et al. 2017). Although genomic and transcriptomic profiling of many solid tumors (including lung, colon, and breast) has revealed high-frequency targetable molecular alterations in other common oncogenes (i.e., EGFR, ALK, ERRB2, etc.), only a small subset of prostate cancers (particularly those with ETS family gene rearrangements) show recurrent targetable alterations; for example, less than $1 \%$ of tumors harbor RAS/RAF family gene rearrangements, FGFR2 gene fusions, or IDH1 mutations (Palanisamy et al. 2010; Prensner et al. 2011; Barbieri et al. 2012; Beltran et al. 2013; Wu et al. 2013; Cancer Genome Atlas Research Network 2015). Despite being among the most frequent molecular alterations in prostate cancer, as of yet there are no specific therapeutics targeted against ETS family gene rearrangements, although small molecular inhibitors targeting PARP1, a mediator of ETS gene fusiondependent transcription, have been investigated for use in advanced prostate cancers with ETS family gene rearrangements (Fig. 4) (Brenner et al. 2011). PARP1 also plays a role in the DNA damage-response pathway, and its inhibition triggers DNA damage-mediated cell death (Do and Chen 2013). This unique protein function suggests that small molecule inhibitors of PARP1 may be useful in the subset of advanced prostate cancers with perturbations in DNA repair pathway genes (Mateo et al. 2017), and, indeed, recent data from a small phase II clinical trial showed high response rates to the PARP1 inhibitor olaparib in patients with metastatic tumors harboring mutations in DNA repair genes (Fig. 4) (Mateo et al. 2015). Interestingly, overexpression of the novel prostate cancerspecific lncRNA PCAT-1 represses BRCA2 expression, which results in a functional BRCAdeficient phenotype ("BRCAness") and suggests that PCAT-1 express may also be a predictive biomarker for PARP1 inhibition in advanced prostate cancer (Fig. 4) (Prensner et al. 2014a). Recent molecular dissection of advanced prostate cancer has also uncovered a role for the bromodomain and extraterminal (BET) proteins in epigenetic regulation of the androgen receptor signaling pathway, and novel smallmolecule BET bromodomain inhibitors may have therapeutic value in advanced tumors with intact androgen receptor pathway activity (i.e., CRPC) (Wyce et al. 2013; Asangani et al. 2014, 2016).

Finally, no review of potential biomarkers for targeted therapeutics for advanced prostate cancer would be complete without briefly discussing the emerging field of immunotherapeutics, which includes therapies that target the CTLA-4 and PD-1/PD-L1 immune checkpoint pathways (Fig. 4) (Littman 2015). Inhibition of these pathways facilitates host immune-mediated tumor cell killing, and although clinical utility of immunotherapeutics for advanced prostate cancer is still under investigation, the success of these targeted therapeutics approaches in other solid tumors is encouraging (Fig. 4) (Hodi et al. 2010; Brahmer et al. 2012; Topalian et al. 2012). As in other tumor types, there is tremendous clinical interest in the development and validation of predictive biomarkers for immunotherapeutic response. For example, the ability of tumor cell PD-L1 expression to predict response to $\mathrm{PD}-1 / \mathrm{PD}$-L1-based targeted immunotherapeutics has been studied in other tumor types with mixed results (Gibney et al. 2016). Although tumor cell PD-L1 expression has not been explicitly examined as a predictive biomarker in advanced prostate cancer, increased tumor cell PD-L1 expression is associated with a higher risk of biochemical recurrence after radical prostatectomy (Gevensleben et al. 2016). In other tumors, additional possible predictive biomarkers for immunotherapeutic response in other tumors include mutational burden, neoantigen burden, and DNA repair mutations (Fig. 4) (Rizvi et al. 2015). As several clinical trials are currently evaluating the efficacy of a variety of immunotherapies in advanced prostate cancer, there will surely be a focused 
A.M. Udager and S.A. Tomlins

effort to develop molecular biomarkers for treatment response. Nevertheless, given the failure of the CTLA-4 inhibitor ipilumimab to improve overall survival in two phase III trials (Kwon et al. 2014; Beer et al. 2017), clinical translation of immunotherapy in prostate cancer will likely be more challenging and may impact fewer patients than other genitourinary malignancies (i.e., urothelial carcinoma and re- nal cell carcinoma) (Motzer et al. 2015; Bellmunt et al. 2017).

Importantly, however, genomic studies clearly show that approximately $1 \%-2 \%$ of CRPC harbor predominantly somatic mutations in DNA mismatch repair genes (most commonly MSH2 and MSH6), leading to hypermutation and microsatellite instability/mismatch repair deficiency (Kumar et al. 2011; Grasso et al.

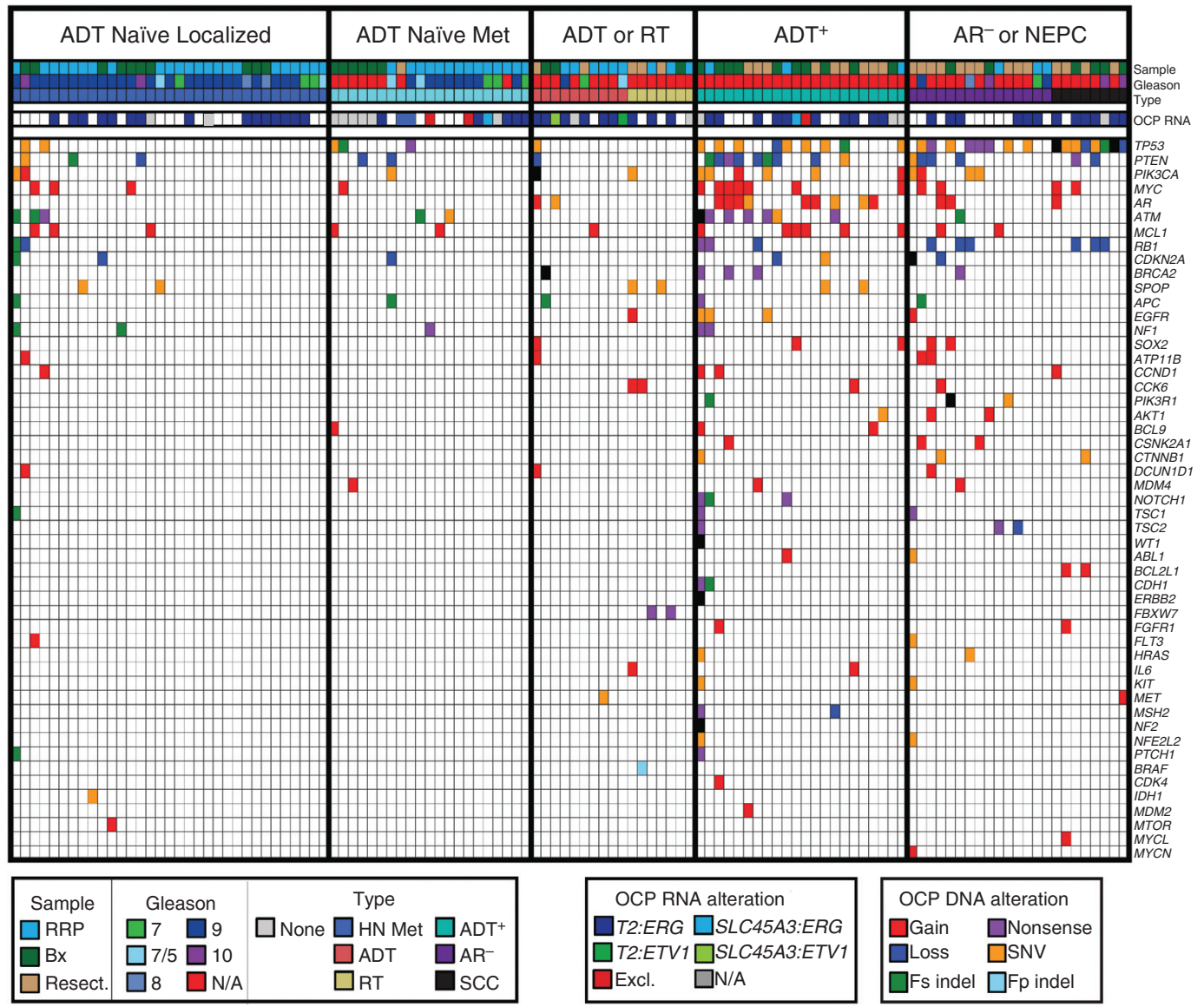

Figure 5. Comprehensive assessment of prostate cancer molecular biomarkers via integrative next-generation DNA and RNA sequencing. Prioritized DNA and RNA alterations identified by multiplexed next-generation sequencing using the Oncomine Comprehensive Panel (OCP) assay from a cohort of formalin fixed paraffin embedded prostate cancer tissue specimens are shown. Samples are grouped according to treatment status (hormone-naïve $[\mathrm{HN}]$, prior androgen deprivation therapy [ADT], radiation therapy [RT], ADT plus RT, and/or chemotherapy $\left[\mathrm{ADT}^{+}\right]$; AR- or NEPC, no [or reduced] AR signaling as indicated by no/focal prostatespecific antigen [PSA] staining or prostatic neuroendocrine/small cell carcinoma [SCC]). Clinicopathological information (including Gleason score) and RNA sequencing results (detected fusions are indicated according to the legend) are shown in the header. (Figure adapted from Hovelson et al. 2015 under a Creative Commons license.) 
2012; Pritchard et al. 2014; Robinson et al. 2015; Abida et al. 2017). The recent FDA approval for pembroluzumab, a PD-1 inhibitor, in any mismatch repair deficient cancer (regardless of site of origin) provides an immediate standard-of-care option for these patients.

\section{CONCLUDING REMARKS}

The past two decades have witnessed a revolution in molecular biomarkers available for the early detection, diagnosis, and treatment of prostate cancer. Given renewed focus on spending and efficacy in all aspects of modern healthcare systems, however, in the coming years there will surely be increasing pressure to justify the clinical benefit of expensive molecular assays, particularly those that evaluate only a single or small group of biomarkers. With this in mind, recent technological advances have spurred the development of comprehensive molecular biomarker assays that assess hundreds or thousands of biomarkers simultaneously. For example, next-generation sequencing technology has facilitated the development of multiplex targeted DNA and RNA sequencing assays that can concurrently assess somatic variants, copy number alterations, and gene expression from minute routine clinical tissue samples, such as prostate core biopsies and minute metastatic tissue foci (Fig. 5) (Grasso et al. 2015; Hovelson et al. 2015; Abida et al. 2017). Not only will such assays provide a focused yet comprehensive overview of the molecular alterations within a given patient's tumor, but simultaneous gene-expression data will facilitate enhanced prognostication and risk stratification. In addition, prospective application of such assays within the context of ongoing clinical trials will provide unique opportunities to evaluate the combinatorial effort of a large number of biomarkers to define the precise set of optimized molecular biomarkers for a given clinical outcome. Overall, in this unfolding era of personalized medicine, advances in molecular biomarkers will continue to influence oncologic care and clinical management of prostate cancer. To drive changes in clinical practice, however, continued rigorous studies are needed to show that such approaches influ- ence treatment decisions and improve outcome in a cost-effective manner.

\section{COMPETING INTEREST STATEMENT}

The University of Michigan has been issued a patent on ETS gene fusions in prostate cancer on which S.A.T. is a coinventor. The diagnostic field of use has been licensed to Hologic/GenProbe, which has sublicensed rights to Roche/ Ventana Medical Systems. S.A.T has received travel support from, and had a sponsored research agreement with, Compendia Bioscience/Life Technologies/ThermoFisher Scientific. S.A.T. has sponsored research agreements with Astellas and GenomeDX. S.A.T. has served as a consultant for and received honoraria from Roche/Ventana Medical Systems, Almac Diagnostics, Janssen, AbbVie, Sanofi, and Astellas/ Medivation. S.A.T. is a cofounder of, consultant for, and Laboratory Director of Strata Oncology. A.M.U. has no disclosures.

\section{ACKNOWLEDGMENTS}

Prostate cancer research in the laboratory of S.A.T. is supported by the National Institutes of Health, the Department of Defense, and the Prostate Cancer Foundation. S.A.T. is supported by the A. Alfred Taubman Medical Research Institute.

\section{REFERENCES}

Abida W, Armenia J, Gopalan A, Brennan R, Walsh M, Barron D, Danila D, Rathkopf D, Morris M, Slovin S, et al. 2017. Prospective genomic profiling of prostate cancer across disease states reveals germline and somatic alterations that may affect clinical decision making. JCO Precis Oncol: 1-16.

Ahearn TU, Pettersson A, Ebot EM, Gerke T, Graff RE, Morais CL, Hicks JL, Wilson KM, Rider JR, Sesso HD, et al. 2016. A prospective investigation of PTEN loss and ERG expression in lethal prostate cancer. J Natl Cancer Inst 108.

Al Olama AA, Kote-Jarai Z, Giles GG, Guy M, Morrison J, Severi G, Leongamornlert DA, Tymrakiewicz M, Jhavar S, Saunders E, et al. 2009. Multiple loci on 8q24 associated with prostate cancer susceptibility. Nat Genet 41: 10581060.

Al Olama AA, Kote-Jarai Z, Berndt SI, Conti DV, Schumacher F, Han Y, Benlloch S, Hazelett DJ, Wang Z, Saunders E, et al. 2014. A meta-analysis of 87,040 indi- 
A.M. Udager and S.A. Tomlins

viduals identifies 23 new susceptibility loci for prostate cancer. Nat Genet 46: 1103-1109.

Al Olama AA, Benlloch S, Antoniou AC, Giles GG, Severi G, Neal DE, Hamdy FC, Donovan JL, Muir K, Schleutker J, et al. 2015. Risk analysis of prostate cancer in PRACTICAL, a Multinational Consortium, using 25 known prostate cancer susceptibility loci. Cancer Epidemiol Biomarkers Prev 24: 1121-1129.

Ankerst DP, Groskopf J, Day JR, Blase A, Rittenhouse H, Pollock BH, Tangen C, Parekh D, Leach RJ, Thompson I. 2008. Predicting prostate cancer risk through incorporation of prostate cancer gene 3. J Urol 180: 1303-1308; discussion 1308 .

Antonarakis ES, Lu C, Wang H, Luber B, Nakazawa M, Roeser JC, Chen Y, Mohammad TA, Chen Y, Fedor HL, et al. 2014. AR-V7 and resistance to enzalutamide and abiraterone in prostate cancer. N Engl J Med 371: 10281038.

Antonarakis ES, Lu C, Luber B, Wang H, Chen Y, Nakazawa M, Nadal R, Paller CJ, Denmeade SR, Carducci MA, et al. 2015. Androgen receptor splice variant 7 and efficacy of taxane chemotherapy in patients with metastatic castration-resistant prostate cancer. JAMA Oncol 1: 582-591.

Antonarakis ES, Armstrong AJ, Dehm SM, Luo J. 2016 Androgen receptor variant-driven prostate cancer: Clinical implications and therapeutic targeting. Prostate Cancer Prostatic Dis 19: 231-241.

Asangani IA, Dommeti VL, Wang X, Malik R, Cieslik M, Yang R, Escara-Wilke J, Wilder-Romans K, Dhanireddy S, Engelke C, et al. 2014. Therapeutic targeting of BET bromodomain proteins in castration-resistant prostate cancer. Nature 510: 278-282.

Asangani IA, Wilder-Romans K, Dommeti VL, Krishnamurthy PM, Apel IJ, Escara-Wilke J, Plymate SR, Navone NM, Wang S, Feng FY, et al. 2016. BET bromodomain inhibitors enhance efficacy and disrupt resistance to AR antagonists in the treatment of prostate cancer. Mol Cancer Res 14: 324-331.

Auprich M, Haese A, Walz J, Pummer K, de la Taille A, Graefen M, de Reijke T, Fisch M, Kil P, Gontero P, et al. 2010. External validation of urinary PCA3-based nomograms to individually predict prostate biopsy outcome. Eur Urol 58: 727-732.

Balk SP, Ko YJ, Bubley GJ. 2003. Biology of prostate-specific antigen. J Clin Oncol 21: 383-391.

Barbieri CE, Baca SC, Lawrence MS, Demichelis F, Blattner M, Theurillat JP, White TA, Stojanov P, Van Allen E, Stransky N, et al. 2012. Exome sequencing identifies recurrent SPOP, FOXA1 and MED12 mutations in prostate cancer. Nat Genet 44: 685-689.

Beer TM, Kwon ED, Drake CG, Fizazi K, Logothetis C, Gravis G, Ganju V, Polikoff J, Saad F, Humanski P, et al. 2017. Randomized, double-blind, phase III trial of ipilimumab versus placebo in asymptomatic or minimally symptomatic patients with metastatic chemotherapy-naive castration-resistant prostate cancer. J Clin Oncol 35: 40-47.

Bellmunt J, de Wit R, Vaughn DJ, Fradet Y, Lee JL, Fong L, Vogelzang NJ, Climent MA, Petrylak DP, Choueiri TK, et al. 2017. Pembrolizumab as second-line therapy for advanced urothelial carcinoma. N Engl J Med 376: 10151026.
Beltran H, Yelensky R, Frampton GM, Park K, Downing SR, MacDonald TY, Jarosz M, Lipson D, Tagawa ST, Nanus DM, et al. 2013. Targeted next-generation sequencing of advanced prostate cancer identifies potential therapeutic targets and disease heterogeneity. Eur Urol 63: 920-926.

Beltran H, Prandi D, Mosquera JM, Benelli M, Puca L, Cyrta J, Marotz C, Giannopoulou E, Chakravarthi BV, Varambally S, et al. 2016. Divergent clonal evolution of castration-resistant neuroendocrine prostate cancer. Nat Med 22: 298-305.

Bishoff JT, Freedland SJ, Gerber L, Tennstedt P, Reid J, Welbourn W, Graefen M, Sangale Z, Tikishvili E, Park J, et al. 2014. Prognostic utility of the cell cycle progression score generated from biopsy in men treated with prostatectomy. J Urol 192: 409-414.

Bjork T, Piironen T, Pettersson K, Lovgren T, Stenman UH, Oesterling JE, Abrahamsson PA, Lilja H. 1996. Comparison of analysis of the different prostate-specific antigen forms in serum for detection of clinically localized prostate cancer. Urology 48: 882-888.

Blume-Jensen P, Berman DM, Rimm DL, Shipitsin M, Putzi M, Nifong TP, Small C, Choudhury S, Capela T, Coupal L, et al. 2015. Development and clinical validation of an in situ biopsy-based multimarker assay for risk stratification in prostate cancer. Clin Cancer Res 21: 2591-2600.

Bottcher R, Hoogland AM, Dits N, Verhoef EI, Kweldam C, Waranecki P, Bangma CH, van Leenders GJ, Jenster G. 2015. Novel long non-coding RNAs are specific diagnostic and prognostic markers for prostate cancer. Oncotarget 6: 4036-4050.

Brahmer JR, Tykodi SS, Chow LQ, Hwu WJ, Topalian SL, Hwu P, Drake CG, Camacho LH, Kauh J, Odunsi K, et al. 2012. Safety and activity of anti-PD-L1 antibody in patients with advanced cancer. $N$ Engl J Med 366: 2455-2465.

Brand TC, Zhang N, Crager MR, Maddala T, Dee A, Sesterhenn IA, Simko JP, Cooperberg MR, Srivastava S, Rosner IL, et al. 2016. Patient-specific meta-analysis of 2 clinical validation studies to predict pathologic outcomes in prostate cancer using the 17-gene genomic prostate score. Urology 89: 69-75.

Brenner JC, Ateeq B, Li Y, Yocum AK, Cao Q, Asangani IA, Patel S, Wang X, Liang H, Yu J, et al. 2011. Mechanistic rationale for inhibition of poly(ADP-ribose) polymerase in ETS gene fusion-positive prostate cancer. Cancer Cell 19: 664-678.

Bryant RJ, Sjoberg DD, Vickers AJ, Robinson MC, Kumar R, Marsden L, Davis M, Scardino PT, Donovan J, Neal DE, et al. 2015. Predicting high-grade cancer at ten-core prostate biopsy using four kallikrein markers measured in blood in the ProtecT Study. J Natl Cancer Inst 107: djv095.

Bussemakers MJ, van Bokhoven A, Verhaegh GW, Smit FP, Karthaus HF, Schalken JA, Debruyne FM, Ru N, Isaacs WB. 1999. DD3: A new prostate-specific gene, highly overexpressed in prostate cancer. Cancer Res 59: 59755979.

Cancer Genome Atlas Research Network. 2015. The molecular taxonomy of primary prostate cancer. Cell 163: 1011-1025.

Castro E, Eeles R. 2012. The role of BRCA1 and BRCA2 in prostate cancer. Asian J Androl 14: 409-414. 
Chua MLK, Lo W, Pintilie M, Murgic J, Lalonde E, Bhandari V, Mahamud O, Gopalan A, Kweldam CF, van Leenders G, et al. 2017. A prostate cancer "Nimbosus": Genomic instability and SChLAP1 dysregulation underpin aggression of intraductal and cribriform subpathologies. Eur Urol doi: 10.1016/j.eururo.2017.04.034.

Chun FK, de la Taille A, van Poppel H, Marberger M, Stenzl A, Mulders PF, Huland H, Abbou CC, Stillebroer AB, van Gils MP, et al. 2009. Prostate cancer gene 3 (PCA3): Development and internal validation of a novel biopsy nomogram. Eur Urol 56: 659-667.

Cooperberg MR, Simko JP, Cowan JE, Reid JE, Djalilvand A, Bhatnagar S, Gutin A, Lanchbury JS, Swanson GP, Stone S, et al. 2013. Validation of a cell-cycle progression gene panel to improve risk stratification in a contemporary prostatectomy cohort. J Clin Oncol 31: 1428-1434.

Cooperberg MR, Davicioni E, Crisan A, Jenkins RB, Ghadessi M, Karnes RJ. 2014. Combined value of validated clinical and genomic risk stratification tools for predicting prostate cancer mortality in a high-risk prostatectomy cohort. Eur Urol 67: 326-333.

Cullen J, Rosner IL, Brand TC, Zhang N, Tsiatis AC, Moncur J, Ali A, Chen Y, Knezevic D, Maddala T, et al. 2014. A biopsy-based 17-gene genomic prostate score predicts recurrence after radical prostatectomy and adverse surgical pathology in a racially diverse population of men with clinically low- and intermediate-risk prostate cancer. Eur Urol 68: 123-131.

Cuzick J, Swanson GP, Fisher G, Brothman AR, Berney DM, Reid JE, Mesher D, Speights VO, Stankiewicz E, Foster CS, et al. 2011. Prognostic value of an RNA expression signature derived from cell cycle proliferation genes in patients with prostate cancer: A retrospective study. Lancet Oncol 12: 245-255.

Cuzick J, Berney DM, Fisher G, Mesher D, Moller H, Reid JE, Perry M, Park J, Younus A, Gutin A, et al. 2012. Prognostic value of a cell cycle progression signature for prostate cancer death in a conservatively managed needle biopsy cohort. Br J Cancer 106: 1095-1099.

Cuzick J, Yang ZH, Fisher G, Tikishvili E, Stone S, Lanchbury JS, Camacho N, Merson S, Brewer D, Cooper CS, et al. 2013. Prognostic value of PTEN loss in men with conservatively managed localised prostate cancer. $\mathrm{Br} \mathrm{J}$ Cancer 108: 2582-2589.

Dalela D, Santiago-Jimenez M, Yousefi K, Karnes RJ, Ross AE, Den RB, Freedland SJ, Schaeffer EM, Dicker AP, Menon M, et al. 2017. Genomic classifier augments the role of pathological features in identifying optimal candidates for adjuvant radiation therapy in patients with prostate cancer: Development and internal validation of a multivariable prognostic model. J Clin Oncol 35: 1982-1990.

de Kok JB, Verhaegh GW, Roelofs RW, Hessels D, Kiemeney LA, Aalders TW, Swinkels DW, Schalken JA. 2002. $D D 3^{P C A 3}$, a very sensitive and specific marker to detect prostate tumors. Cancer Res 62: 2695-2698.

de la Calle C, Patil D, Wei JT, Scherr DS, Sokoll L, Chan DW, Siddiqui J, Mosquera JM, Rubin MA, Sanda MG. 2015. Multicenter evaluation of the prostate health index to detect aggressive prostate cancer in biopsy naive men. J Urol 194: 65-72.
Del Re M, Biasco E, Crucitta S, Derosa L, Rofi E, Orlandini C, Miccoli M, Galli L, Falcone A, Jenster GW, et al. 2017. The detection of androgen receptor splice variant 7 in plasmaderived exosomal RNA strongly predicts resistance to hormonal therapy in metastatic prostate cancer patients. Eur Urol 71: 680-687.

Den RB, Yousefi K, Trabulsi EJ, Abdollah F, Choeurng V, Feng FY, Dicker AP, Lallas CD, Gomella LG, Davicioni E, et al. 2015. Genomic classifier identifies men with adverse pathology after radical prostatectomy who benefit from adjuvant radiation therapy. J Clin Oncol 33: 944-951.

Deras IL, Aubin SM, Blase A, Day JR, Koo S, Partin AW, Ellis WJ, Marks LS, Fradet Y, Rittenhouse H, et al. 2008. PCA3: A molecular urine assay for predicting prostate biopsy outcome. J Urol 179: 1587-1592.

Do K, Chen AP. 2013. Molecular pathways: Targeting PARP in cancer treatment. Clin Cancer Res 19: 977-984.

Eeles RA, Kote-Jarai Z, Al Olama AA, Giles GG, Guy M, Severi G, Muir K, Hopper JL, Henderson BE, Haiman CA, et al. 2009. Identification of seven new prostate cancer susceptibility loci through a genome-wide association study. Nat Genet 41: 1116-1121.

Enokida $\mathrm{H}$, Shiina $\mathrm{H}$, Urakami S, Igawa $\mathrm{M}$, Ogishima T, Li LC, Kawahara M, Nakagawa M, Kane CJ, Carroll PR, et al. 2005. Multigene methylation analysis for detection and staging of prostate cancer. Clin Cancer Res 11: 6582-6588.

Epstein JI, Amin MB, Beltran H, Lotan TL, Mosquera JM, Reuter VE, Robinson BD, Troncoso P, Rubin MA. 2014. Proposed morphologic classification of prostate cancer with neuroendocrine differentiation. Am J Surg Pathol 38: 756-767.

Erho N, Crisan A, Vergara IA, Mitra AP, Ghadessi M, Buerki C, Bergstralh EJ, Kollmeyer T, Fink S, Haddad Z, et al. 2013. Discovery and validation of a prostate cancer genomic classifier that predicts early metastasis following radical prostatectomy. PLoS ONE 8: e66855.

Ewing CM, Ray AM, Lange EM, Zuhlke KA, Robbins CM, Tembe WD, Wiley KE, Isaacs SD, Johng D, Wang Y, et al. 2012. Germline mutations in HOXB13 and prostatecancer risk. $N$ Engl J Med 366: 141-149.

Freedland SJ, Choeurng V, Howard L, De Hoedt A, du Plessis M, Yousefi K, Lam LL, Buerki C, Ra S, Robbins B, et al. 2016. Utilization of a genomic classifier for prediction of metastasis following salvage radiation therapy after radical prostatectomy. Eur Urol 70: 588-596.

Gevensleben H, Dietrich D, Golletz C, Steiner S, Jung M, Thiesler T, Majores M, Stein J, Uhl B, Muller S, et al. 2016. The immune checkpoint regulator PD-L1 is highly expressed in aggressive primary prostate cancer. Clin Cancer Res 22: 1969-1977.

Gibney GT, Weiner LM, Atkins MB. 2016. Predictive biomarkers for checkpoint inhibitor-based immunotherapy. Lancet Oncol 17: e542-e551.

Grasso CS, Wu YM, Robinson DR, Cao X, Dhanasekaran SM, Khan AP, Quist MJ, Jing X, Lonigro RJ, Brenner JC, et al. 2012. The mutational landscape of lethal castration-resistant prostate cancer. Nature 487: 239-243.

Grasso CS, Cani AK, Hovelson DH, Quist MJ, Douville NJ, Yadati V, Amin AM, Nelson PS, Betz BL, Liu CJ, et al. 2015. Integrative molecular profiling of routine clinical prostate cancer specimens. Ann Oncol 26: 1110-1118. 
A.M. Udager and S.A. Tomlins

Gronberg H, Adolfsson J, Aly M, Nordström T, Wiklund P Brandberg Y, Thompson J, Wiklund F, Lindberg J, Clements $\mathrm{M}$, et al. 2015. Prostate cancer screening in men aged 50-69 years (STHLM3): A prospective population-based diagnostic study. Lancet Oncol 16: 1667-1676.

Guedes LB, Tosoian JJ, Hicks J, Ross AE, Lotan TL. 2017. PTEN loss in Gleason Score $3+4=7$ prostate biopsies is associated with nonorgan confined disease at radical prostatectomy. J Urol 197: 1054-1059.

Han B, Mehra R, Suleman K, Tomlins SA, Wang L, Singhal N, Linetzky KA, Palanisamy N, Zhou M, Chinnaiyan AM, et al. 2009. Characterization of ETS gene aberrations in select histologic variants of prostate carcinoma. Mod Pathol 22: 1176-1185.

He H, Magi-Galluzzi C, Li J, Carver P, Falzarano S, Smith K, Rubin MA, Zhou M. 2011. The diagnostic utility of novel immunohistochemical marker ERG in the workup of prostate biopsies with "atypical glands suspicious for cancer.” Am J Surg Pathol 35: 608-614.

Hessels D, Klein Gunnewiek JM, van Oort I, Karthaus HF, van Leenders GJ, van Balken B, Kiemeney LA, Witjes JA, Schalken JA. 2003. $D D 3^{P C A 3}$-based molecular urine analysis for the diagnosis of prostate cancer. Eur Urol 44: 815; discussion 15-16.

Hessels D, Smit FP, Verhaegh GW, Witjes JA, Cornel EB, Schalken JA. 2007. Detection of TMPRSS2-ERG fusion transcripts and prostate cancer antigen 3 in urinary sediments may improve diagnosis of prostate cancer. Clin Cancer Res 13: 5103-5108.

Hickman RA, Yu H, Li J, Kong M, Shah RB, Zhou M, Melamed J, Deng FM. 2017. Atypical intraductal cribriform proliferations of the prostate exhibit similar molecular and clinicopathologic characteristics as intraductal carcinoma of the prostate. Am J Surg Pathol 41: 550-556.

Hodi FS, O'Day SJ, McDermott DF, Weber RW, Sosman JA, Haanen JB, Gonzalez R, Robert C, Schadendorf D, Hassel JC, et al. 2010. Improved survival with ipilimumab in patients with metastatic melanoma. $N$ Engl J Med 363: 711-723.

Hovelson DH, McDaniel AS, Cani AK, Johnson B, Rhodes K, Williams PD, Bandla S, Bien G, Choppa P, Hyland F, et al. 2015. Development and validation of a scalable next-generation sequencing system for assessing relevant somatic variants in solid tumors. Neoplasia 17: 385-399.

Huang FW, Hodis E, Xu MJ, Kryukov GV, Chin L, Garraway LA. 2013. Highly recurrent TERT promoter mutations in human melanoma. Science 339: 957-959.

Iczkowski KA, MacLennan GT, Bostwick DG. 1997. Atypica small acinar proliferation suspicious for malignancy in prostate needle biopsies: Clinical significance in 33 cases. Am J Surg Pathol 21: 1489-1495.

Iyer MK, Niknafs YS, Malik R, Singhal U, Sahu A, Hosono Y, Barrette TR, Prensner JR, Evans JR, Zhao S, et al. 2015. The landscape of long noncoding RNAs in the human transcriptome. Nat Genet 47: 199-208.

Jiang Z, Li C, Fischer A, Dresser K, Woda BA. 2005. Using an AMACR (P504S)/343E12/p63 cocktail for the detection of small focal prostate carcinoma in needle biopsy specimens. Am J Clin Pathol 123: 231-236.

Karnes RJ, Bergstralh EJ, Davicioni E, Ghadessi M, Buerki C, Mitra AP, Crisan A, Erho N, Vergara IA, Lam LL, et al. 2013. Validation of a genomic classifier that predicts metastasis following radical prostatectomy in an at risk patient population. J Urol 190: 2047-2053.

Karnes RJ, Choeurng V, Ross AE, Schaeffer EM, Klein EA, Freedland SJ, Erho N, Yousefi K, Takhar M, Davicioni E, et al. 2017. Validation of a genomic risk classifier to predict prostate cancer-specific mortality in men with adverse pathologic features. Eur Urol doi: 10.1016/j. eururo.2017.03.036.

Kattan MW. 2003. Judging new markers by their ability to improve predictive accuracy. J Natl Cancer Inst 95: 634635.

Killela PJ, Reitman ZJ, Jiao Y, Bettegowda C, Agrawal N, Diaz LA Jr., Friedman AH, Friedman H, Gallia GL, Giovanella BC, et al. 2013. TERT promoter mutations occur frequently in gliomas and a subset of tumors derived from cells with low rates of self-renewal. Proc Natl Acad Sci 110: 6021-6026.

Klein EA, Cooperberg MR, Magi-Galluzzi C, Simko JP, Falzarano SM, Maddala T, Chan JM, Li J, Cowan JE, Tsiatis AC, et al. 2014. A 17-gene assay to predict prostate cancer aggressiveness in the context of Gleason grade heterogeneity, tumor multifocality, and biopsy undersampling. Eur Urol 66: 550-560.

Klein EA, Yousefi K, Haddad Z, Choeurng V, Buerki C, Stephenson AJ, Li J, Kattan MW, Magi-Galluzzi C, Davicioni E. 2015. A genomic classifier improves prediction of metastatic disease within 5 years after surgery in nodenegative high-risk prostate cancer patients managed by radical prostatectomy without adjuvant therapy. Eur Urol 67: 778-786.

Klein EA, Haddad Z, Yousefi K, Lam LL, Wang Q, Choeurng V, Palmer-Aronsten B, Buerki C, Davicioni E, Li J, et al. 2016. Decipher genomic classifier measured on prostate biopsy predicts metastasis risk. Urology 90: 148-152.

Knezevic D, Goddard AD, Natraj N, Cherbavaz DB, ClarkLangone KM, Snable J, Watson D, Falzarano SM, MagiGalluzzi C, Klein EA, et al. 2013. Analytical validation of the Oncotype DX prostate cancer assay-A clinical RT-PCR assay optimized for prostate needle biopsies. BMC Genomics 14: 690.

Krohn A, Diedler T, Burkhardt L, Mayer PS, De Silva C, Meyer-Kornblum M, Kotschau D, Tennstedt P, Huang J, Gerhauser C, et al. 2012. Genomic deletion of PTEN is associated with tumor progression and early PSA recurrence in ERG fusion-positive and fusion-negative prostate cancer. Am J Pathol 181: 401-412.

Kumar A, White TA, MacKenzie AP, Clegg N, Lee C, Dumpit RF, Coleman I, Ng SB, Salipante SJ, Rieder MJ, et al. 2011. Exome sequencing identifies a spectrum of mutation frequencies in advanced and lethal prostate cancers. Proc Natl Acad Sci 108: 17087-17092.

Kwon ED, Drake CG, Scher HI, Fizazi K, Bossi A, van den Eertwegh AJ, Krainer M, Houede N, Santos R, Mahammedi $\mathrm{H}$, et al. 2014. Ipilimumab versus placebo after radiotherapy in patients with metastatic castration-resistant prostate cancer that had progressed after docetaxel chemotherapy (CA184-043): A multicentre, randomised, double-blind, phase 3 trial. Lancet Oncol 15: 700-712.

Laxman B, Tomlins SA, Mehra R, Morris DS, Wang L, Helgeson BE, Shah RB, Rubin MA, Wei JT, Chinnaiyan AM. 2006. Noninvasive detection of TMPRSS2:ERG fusion 
transcripts in the urine of men with prostate cancer Neoplasia 8: 885-888.

Laxman B, Morris DS, Yu J, Siddiqui J, Cao J, Mehra R, Lonigro RJ, Tsodikov A, Wei JT, Tomlins SA, et al. 2008. A first-generation multiplex biomarker analysis of urine for the early detection of prostate cancer. Cancer Res 68: 645-649.

Leyten GH, Hessels D, Smit FP, Jannink SA, de Jong H, Melchers WJ, Cornel EB, de Reijke TM, Vergunst H, Kil $\mathrm{P}$, et al. 2015. Identification of a candidate gene panel for the early diagnosis of prostate cancer. Clin Cancer Res 21: 3061-3070.

Lilja H, Ulmert D, Vickers AJ. 2008. Prostate-specific antigen and prostate cancer: Prediction, detection and monitoring. Nat Rev 8: 268-278.

Littman DR. 2015. Releasing the brakes on cancer immunotherapy. Cell 162: 1186-1190.

Loeb S, Sanda MG, Broyles DL, Shin SS, Bangma CH, Wei JT, Partin AW, Klee GG, Slawin KM, Marks LS, et al. 2014 The prostate health index selectively identifies clinically significant prostate cancer. J Urol 194: 1825-1826.

Lotan TL, Gupta NS, Wang W, Toubaji A, Haffner MC, Chaux A, Hicks JL, Meeker AK, Bieberich CJ, De Marzo AM, et al. 2011a. ERG gene rearrangements are common in prostatic small cell carcinomas. Mod Pathol 24: 820828.

Lotan TL, Gurel B, Sutcliffe S, Esopi D, Liu W, Xu J, Hicks JL, Park BH, Humphreys E, Partin AW, et al. 2011b. PTEN protein loss by immunostaining: analytic validation and prognostic indicator for a high risk surgical cohort of prostate cancer patients. Clin Cancer Res 17: 6563-6573.

Lotan TL, Gumuskaya B, Rahimi H, Hicks JL, Iwata T, Robinson BD, Epstein JI, De Marzo AM. 2013. Cytoplasmic PTEN protein loss distinguishes intraductal carcinoma of the prostate from high-grade prostatic intraepithelial neoplasia. Mod Pathol 26: 587-603.

Lotan TL, Carvalho FL, Peskoe SB, Hicks JL, Good J, Fedor HL, Humphreys E, Han M, Platz EA, Squire JA, et al. 2015. PTEN loss is associated with upgrading of prostate cancer from biopsy to radical prostatectomy. Mod Pathol 28: $128-137$.

Lotan TL, Wei W, Ludkovski O, Morais CL, Guedes LB, Jamaspishvili T, Lopez K, Hawley ST, Feng Z, Fazli L, et al. 2016. Analytic validation of a clinical-grade PTEN immunohistochemistry assay in prostate cancer by comparison with PTEN FISH. Mod Pathol 29: 904-914.

Magers M, Kunju LP, Wu A. 2015. Intraductal carcinoma of the prostate: Morphologic features, differential diagnoses, significance, and reporting practices. Arch Pathol Lab Med 139: 1234-1241.

Mateo J, Carreira S, Sandhu S, Miranda S, Mossop H, PerezLopez R, Nava Rodrigues D, Robinson D, Omlin A, Tunariu N, et al. 2015. DNA-repair defects and Olaparib in metastatic prostate cancer. N Engl J Med 373: 1697-1708.

Mateo J, Boysen G, Barbieri CE, Bryant HE, Castro E, Nelson PS, Olmos D, Pritchard CC, Rubin MA, de Bono JS. 2017. DNA repair in prostate cancer: Biology and clinical implications. Eur Urol 71: 417-425.

McKiernan J, Donovan MJ, O’Neill V, Bentink S, Noerholm M, Belzer S, Skog J, Kattan MW, Partin A, Andriole G, et al. 2016. A novel urine exosome gene expression assay to predict high-grade prostate cancer at initial biopsy. JAMA Oncol 2: 882-889.

Mehra R, Tomlins SA, Shen R, Nadeem O, Wang L, Wei JT, Pienta KJ, Ghosh D, Rubin MA, Chinnaiyan AM, et al. 2007. Comprehensive assessment of TMPRSS2 and ETS family gene aberrations in clinically localized prostate cancer. Mod Pathol 20: 538-544.

Mehra R, Shi Y, Udager AM, Prensner JR, Sahu A, Iyer MK, Siddiqui J, Cao X, Wei J, Jiang H, et al. 2014. A novel RNA in situ hybridization assay for the long noncoding RNA SChLAP1 predicts poor clinical outcome after radical prostatectomy in clinically localized prostate cancer. Neoplasia 16: 1121-1127.

Mehra R, Udager AM, Ahearn TU, Cao X, Feng FY, Loda M, Petimar JS, Kantoff P, Mucci LA, Chinnaiyan AM. 2016. Overexpression of the long non-coding RNA SChLAP1 independently predicts lethal prostate cancer. Eur Urol 70: $549-552$

Merdan S, Tomlins SA, Barnett CL, Morgan TM, Montie JE, Wei JT, Denton BT. 2015. Assessment of long-term outcomes associated with urinary prostate cancer antigen 3 and TMPRSS2:ERG gene fusion at repeat biopsy. Cancer 121: 4071-4079.

Mikolajczyk SD, Marker KM, Millar LS, Kumar A, Saedi MS, Payne JK, Evans CL, Gasior CL, Linton HJ, Carpenter P. et al. 2001. A truncated precursor form of prostate-specific antigen is a more specific serum marker of prostate cancer. Cancer Res 61: 6958-6963.

Morais CL, Han JS, Gordetsky J, Nagar MS, Anderson AE, Lee S, Hicks JL, Zhou M, Magi-Galluzzi C, Shah RB, et al. 2015. Utility of PTEN and ERG immunostaining for distinguishing high-grade PIN from intraductal carcinoma of the prostate on needle biopsy. Am J Surg Pathol 39: 169-178.

Mottet N, Bellmunt J, Bolla M, Briers E, Cumberbatch MG, De Santis M, Fossati N, Gross T, Henry AM, Joniau S, et al. 2017. EAU-ESTRO-SIOG guidelines on prostate cancer. Part 1: Screening, diagnosis, and local treatment with $\mathrm{cu}-$ rative intent. Eur Urol 71: 618-629.

Motzer RJ, Escudier B, McDermott DF, George S, Hammers HJ, Srinivas S, Tykodi SS, Sosman JA, Procopio G, Plimack ER, et al. 2015. Nivolumab versus everolimus in advanced renal-cell carcinoma. $N$ Engl $J$ Med 373: 1803-1813.

Nguyen PL, Haddad Z, Ross AE, Martin NE, Deheshi S, Lam LLC, Chelliserry J, Tosoian JJ, Lotan TL, Spratt DE, et al. 2017. Ability of a genomic classifier to predict metastasis and prostate cancer-specific mortality after radiation or surgery based on needle biopsy specimens. Eur Urol 72: 845-852.

Nordström T, Vickers A, Assel M, Lilja H, Grönberg H, Eklund M. 2014. Comparison between the four-kallikrein panel and prostate health index for predicting prostate cancer. Eur Urol 68: 139-146.

Onstenk W, Sieuwerts AM, Kraan J, Van M, Nieuweboer AJ, Mathijssen RH, Hamberg P, Meulenbeld HJ, De Laere B, Dirix LY, et al. 2015. Efficacy of cabazitaxel in castrationresistant prostate cancer is independent of the presence of AR-V7 in circulating tumor cells. Eur Urol 68: 939-945.

Palanisamy N, Ateeq B, Kalyana-Sundaram S, Pflueger D, Ramnarayanan K, Shankar S, Han B, Cao Q, Cao X, Suleman K, et al. 2010. Rearrangements of the RAF kinase 
A.M. Udager and S.A. Tomlins

pathway in prostate cancer, gastric cancer and melanoma. Nat Med 16: 793-798.

Parekh DJ, Punnen S, Sjoberg DD, Asroff SW, Bailen JL Cochran JS, Concepcion R, David RD, Deck KB, Dumbadze I, et al. 2014. A multi-institutional prospective trial in the USA confirms that the 4 Kscore accurately identifies men with high-grade prostate cancer. Eur Urol 68: 464470.

Park K, Tomlins SA, Mudaliar KM, Chiu YL, Esgueva R, Mehra R, Suleman K, Varambally S, Brenner JC, MacDonald T, et al. 2010. Antibody-based detection of $E R G$ rearrangement-positive prostate cancer. Neoplasia 12: 590-598.

Partin AW, Van Neste L, Klein EA, Marks LS, Gee JR, Troyer DA, Rieger-Christ K, Jones JS, Magi-Galluzzi C, Mangold LA, et al. 2014. Clinical validation of an epigenetic assay to predict negative histopathological results in repeat prostate biopsies. J Urol 192: 1081-1087.

Pashayan N, Duffy SW, Neal DE, Hamdy FC, Donovan JL, Martin RM, Harrington P, Benlloch S, Amin Al Olama A Shah M, et al. 2015. Implications of polygenic riskstratified screening for prostate cancer on overdiagnosis. Genet Med 17: 789-795.

Phin S, Moore MW, Cotter PD. 2013. Genomic rearrangements of PTEN in prostate cancer. Front Oncol 3: 240.

Picanco-Albuquerque CG, Morais CL, Carvalho FL, Peskoe SB, Hicks JL, Ludkovski O, Vidotto T, Fedor H, Humphreys E, Han M, et al. 2016. In prostate cancer needle biopsies, detections of PTEN loss by fluorescence in situ hybridization (FISH) and by immunohistochemistry (IHC) are concordant and show consistent association with upgrading. Virchows Arch 468: 607-617.

Prensner JR, Chinnaiyan AM. 2011. The emergence of lncRNAs in cancer biology. Cancer Discov 1: 391-407.

Prensner JR, Iyer MK, Balbin OA, Dhanasekaran SM, Cao Q, Brenner JC, Laxman B, Asangani IA, Grasso CS, Kominsky HD, et al. 2011. Transcriptome sequencing across a prostate cancer cohort identifies PCAT-1, an unannotated lincRNA implicated in disease progression. Nat Biotechnol 29: 742-749.

Prensner JR, Iyer MK, Sahu A, Asangani IA, Cao Q, Patel L, Vergara IA, Davicioni E, Erho N, Ghadessi M, et al. 2013. The long noncoding RNA SChLAP1 promotes aggressive prostate cancer and antagonizes the SWI/SNF complex. Nat Genet 45: 1392-1398.

Prensner JR, Chen W, Iyer MK, Cao Q, Ma T, Han S, Sahu A, Malik R, Wilder-Romans K, Navone N, et al. 2014a. PCAT-1, a long noncoding RNA, regulates BRCA2 and controls homologous recombination in cancer. Cancer Res 74: 1651-1660.

Prensner JR, Zhao S, Erho N, Schipper M, Iyer MK, Dhanasekaran SM, Magi-Galluzzi C, Mehra R, Sahu A, Siddiqui J, et al. 2014b. RNA biomarkers associated with metastatic progression in prostate cancer: A multi-institutional high-throughput analysis of SChLAP1. Lancet Oncol 15: 1469-1480.

Pritchard CC, Morrissey C, Kumar A, Zhang X, Smith C, Coleman I, Salipante SJ, Milbank J, Yu M, Grady WM, et al. 2014. Complex MSH2 and MSH6 mutations in hypermutated microsatellite unstable advanced prostate cancer. $\mathrm{Nat}$ Commun 5: 4988.
Pritchard CC, Mateo J, Walsh MF, De Sarkar N, Abida W, Beltran H, Garofalo A, Gulati R, Carreira S, Eeles R, et al. 2016. Inherited DNA-repair gene mutations in men with metastatic prostate cancer. N Engl J Med 375: 443-453.

Recker F, Kwiatkowski MK, Piironen T, Pettersson K, Huber A, Lummen G, Tscholl R. 2000. Human glandular kallikrein as a tool to improve discrimination of poorly differentiated and non-organ-confined prostate cancer compared with prostate-specific antigen. Urology 55: 481-485.

Rizvi NA, Hellmann MD, Snyder A, Kvistborg P, Makarov V, Havel JJ, Lee W, Yuan J, Wong P, Ho TS, et al. 2015. Cancer immunology. Mutational landscape determines sensitivity to PD-1 blockade in non-small cell lung cancer. Science 348: 124-128.

Robinson D, Van Allen EM, Wu YM, Schultz N, Lonigro RJ, Mosquera JM, Montgomery B, Taplin ME, Pritchard CC, Attard G, et al. 2015. Integrative clinical genomics of advanced prostate cancer. Cell 161: 1215-1228.

Ross AE, Johnson MH, Yousefi K, Davicioni E, Netto GJ, Marchionni L, Fedor HL, Glavaris S, Choeurng V, Buerki C, et al. 2016. Tissue-based genomics augments postprostatectomy risk stratification in a natural history cohort of intermediate- and high-risk men. Eur Urol 69: 157-165.

Salami SS, Schmidt F, Laxman B, Regan MM, Rickman DS, Scherr D, Bueti G, Siddiqui J, Tomlins SA, Wei JT, et al. 2013. Combining urinary detection of TMPRSS2:ERG and PCA3 with serum PSA to predict diagnosis of prostate cancer. Urologic Oncol 31: 566-571.

Sanda MG, Feng Z, Howard DH, Tomlins SA, Sokoll LJ, Chan DW, Regan MM, Groskopf J, Chipman J, Patil $\mathrm{DH}$, et al. 2017. Association between combined TMPRSS2:ERG and PCA3 RNA urinary testing and detection of aggressive prostate cancer. JAMA Oncol 3: 1085-1093.

Sathyanarayana UG, Birch C, Nagle RB, Tomlins SA, Palanisamy N, Zhang W, Hubbard A, Brunhoeber P, Wang Y, Tang L. 2015. Determination of optimum formalin fixation duration for prostate needle biopsies for immunohistochemistry and quantum dot FISH analysis. Appl Immunohistochem Mol Morphol 23: 364-373.

Sauter G, Steurer S, Clauditz TS, Krech T, Wittmer C, Lutz F, Lennartz M, Janssen T, Hakimi N, Simon R, et al. 2016. Clinical utility of quantitative Gleason grading in prostate biopsies and prostatectomy specimens. Eur Urol 69: 592598.

Schelling LA, Williamson SR, Zhang S, Yao JL, Wang M, Huang J, Montironi R, Lopez-Beltran A, Emerson RE, Idrees MT, et al. 2013. Frequent TMPRSS2-ERG rearrangement in prostatic small cell carcinoma detected by fluorescence in situ hybridization: The superiority of fluorescence in situ hybridization over ERG immunohistochemistry. Hum Pathol 44: 2227-2233.

Scher HI, Lu D, Schreiber NA, Louw J, Graf RP, Vargas HA, Johnson A, Jendrisak A, Bambury R, Danila D, et al. 2016. Association of AR-V7 on circulating tumor cells as a treatment-specific biomarker with outcomes and survival in castration-resistant prostate cancer. JAMA Oncol 2: 1441-1449.

Scher HI, Graf RP, Schreiber NA, McLaughlin B, Lu D, Louw J, Danila DC, Dugan L, Johnson A, Heller G, et al. 2017. 
Nuclear-specific AR-V7 protein localization is necessary to guide treatment selection in metastatic castration-resistant prostate cancer. Eur Urol 71: 874-882.

Shieh Y, Eklund M, Sawaya GF, Black WC, Kramer BS, Esserman LJ. 2016. Population-based screening for cancer: Hope and hype. Nat Rev Clin Oncol 13: 550-565.

Siegel RL, Miller KD, Jemal A. 2017. Cancer statistics, 2017. CA Cancer J Clin 67: 7-30.

Sommariva S, Tarricone R, Lazzeri M, Ricciardi W, Montorsi F. 2014. Prognostic value of the cell cycle progression score in patients with prostate cancer: A systematic review and meta-analysis. Eur Urol 69: 107-115.

Spratt DE, Yousefi K, Deheshi S, Ross AE, Den RB, Schaeffer EM, Trock BJ, Zhang J, Glass AG, Dicker AP, et al. 2017. Individual patient-level meta-analysis of the performance of the decipher genomic classifier in high-risk men after prostatectomy to predict development of metastatic disease. J Clin Oncol 35: 1991-1998.

Stattin P, Vickers AJ, Sjoberg DD, Johansson R, Granfors T, Johansson M, Pettersson K, Scardino PT, Hallmans G, Lilja H. 2015. Improving the specificity of screening for lethal prostate cancer using prostate-specific antigen and a panel of kallikrein markers: A nested case-control study. Eur Urol 68: 207-213.

Steuber T, Nurmikko P, Haese A, Pettersson K, Graefen M, Hammerer P, Huland H, Lilja H. 2002. Discrimination of benign from malignant prostatic disease by selective measurements of single chain, intact free prostate specific antigen. J Urol 168: 1917-1922.

Steuber T, Vickers AJ, Serio AM, Vaisanen V, Haese A, Pettersson K, Eastham JA, Scardino PT, Huland H, Lilja H. 2007. Comparison of free and total forms of serum human kallikrein 2 and prostate-specific antigen for prediction of locally advanced and recurrent prostate cancer. Clin Chem 53: 233-240.

Tan HL, Sood A, Rahimi HA, Wang W, Gupta N, Hicks J, Mosier S, Gocke CD, Epstein JI, Netto GJ, et al. 2014. Rb loss is characteristic of prostatic small cell neuroendocrine carcinoma. Clin Cancer Res 20: 890-903.

Thompson IM Jr, Goodman PJ, Tangen CM, Parnes HL, Minasian LM, Godley PA, Lucia MS, Ford LG. 2013. Long-term survival of participants in the prostate cancer prevention trial. N Engl J Med 369: 603-610.

Thorek DL, Evans MJ, Carlsson SV, Ulmert D, Lilja H. 2013. Prostate-specific kallikrein-related peptidases and their relation to prostate cancer biology and detection. Established relevance and emerging roles. Thromb Haemost 110: 484-492.

Tomlins SA, Rhodes DR, Perner S, Dhanasekaran SM, Mehra R, Sun XW, Varambally S, Cao X, Tchinda J, Kuefer R, et al. 2005. Recurrent fusion of TMPRSS2 and ETS transcription factor genes in prostate cancer. Science 310: 644-648.

Tomlins SA, Aubin SM, Siddiqui J, Lonigro RJ, Sefton-Miller L, Miick S, Williamsen S, Hodge P, Meinke J, Blase A, et al 2011. Urine TMPRSS2:ERG fusion transcript stratifies prostate cancer risk in men with elevated serum PSA. Sci Transl Med 3: 94ra72.

Tomlins SA, Palanisamy N, Siddiqui J, Chinnaiyan AM, Kunju LP. 2012. Antibody-based detection of ERG rearrangements in prostate core biopsies, including diagnos- tically challenging cases: ERG staining in prostate core biopsies. Arch Pathol Lab Med 136: 935-946.

Tomlins SA, Day JR, Lonigro RJ, Hovelson DH, Siddiqui J, Kunju LP, Dunn RL, Meyer S, Hodge P, Groskopf J, et al. 2016. Urine TMPRSS2:ERG plus PCA3 for individualized prostate cancer risk assessment. Eur Urol 70: 45-53.

Topalian SL, Hodi FS, Brahmer JR, Gettinger SN, Smith DC, McDermott DF, Powderly JD, Carvajal RD, Sosman JA, Atkins MB, et al. 2012. Safety, activity, and immune correlates of anti-PD-1 antibody in cancer. NEngl J Med 366: 2443-2454.

Tosoian JJ, Carter HB, Lepor A, Loeb S. 2016. Active surveillance for prostate cancer: Current evidence and contemporary state of practice. Nat Rev Urol 13: 205-215.

Tosoian JJ, Druskin SC, Andreas D, Mullane P, Chappidi M, Joo S, Ghabili K, Agostino J, Macura KJ, Carter HB, et al. 2017a. Use of the Prostate Health Index for detection of prostate cancer: Results from a large academic practice. Prostate Cancer Prostatic Dis 20: 228-233.

Tosoian JJ, Druskin SC, Andreas D, Mullane P, Chappidi M, Joo S, Ghabili K, Mamawala M, Agostino J, Carter HB, et al. 2017b. Prostate Health Index density improves detection of clinically significant prostate cancer. $B J U$ Int doi: 10.1111/bju.13762.

Tosoian JT, Chappidi MR, Bishoff JT, Freedland SJ, Reid J, Brawer M, Stone S, Schlomm T, Ross AE. 2017c. Prognostic utility of biopsy-derived cell cycle progression score in patients with NCCN low-risk prostate cancer undergoing radical prostatectomy: Implications for treatment guidance. BJU Int doi: 10.1111/bju.13911.

Trock BJ, Brotzman MJ, Mangold LA, Bigley JW, Epstein JI, McLeod D, Klein EA, Jones JS, Wang S, McAskill T, et al. 2012. Evaluation of GSTP1 and APC methylation as indicators for repeat biopsy in a high-risk cohort of men with negative initial prostate biopsies. BJU Int 110: 56-62.

Trock BJ, Fedor H, Gurel B, Jenkins RB, Knudsen BS, Fine SW, Said JW, Carter HB, Lotan TL, De Marzo AM. 2016. PTEN loss and chromosome 8 alterations in Gleason grade 3 prostate cancer cores predicts the presence of un-sampled grade 4 tumor: Implications for active surveillance. Mod Pathol 29: 764-771.

Tsai H, Morais CL, Alshalalfa M, Tan HL, Haddad Z, Hicks J, Gupta N, Epstein JI, Netto GJ, Isaacs WB, et al. 2015. Cyclin D1 loss distinguishes prostatic small-cell carcinoma from most prostatic adenocarcinomas. Clin Cancer Res 21: 5619-5629.

Van Neste L, Hendriks RJ, Dijkstra S, Trooskens G, Cornel EB, Jannink SA, de Jong H, Hessels D, Smit FP, Melchers WJ, et al. 2016. Detection of high-grade prostate cancer using a urinary molecular biomarker-based risk score. Eur Urol 70: 740-748.

Verhagen PC, van Duijn PW, Hermans KG, Looijenga LH, van Gurp RJ, Stoop H, van der Kwast TH, Trapman J. 2006. The PTEN gene in locally progressive prostate cancer is preferentially inactivated by bi-allelic gene deletion. J Pathol 208: 699-707.

Vickers AJ, Cronin AM, Aus G, Pihl CG, Becker C, Pettersson K, Scardino PT, Hugosson J, Lilja H. 2008. A panel of kallikrein markers can reduce unnecessary biopsy for prostate cancer: Data from the European Randomized Study of Prostate Cancer Screening in Goteborg, Sweden. $B M C$ Med 6: 19. 
A.M. Udager and S.A. Tomlins

Vickers A, Cronin A, Roobol M, Savage C, Peltola M, Pettersson K, Scardino PT, Schroder F, Lilja H. 2010a. Reducing unnecessary biopsy during prostate cancer screening using a four-kallikrein panel: An independent replication. J Clin Oncol 28: 2493-2498.

Vickers AJ, Cronin AM, Roobol MJ, Savage CJ, Peltola M, Pettersson K, Scardino PT, Schroder FH, Lilja H. 2010b. A four-kallikrein panel predicts prostate cancer in men with recent screening: Data from the European Randomized Study of Screening for Prostate Cancer, Rotterdam. Clin Cancer Res 16: 3232-3239.

Vickers AJ, Gupta A, Savage CJ, Pettersson K, Dahlin A, Bjartell A, Manjer J, Scardino PT, Ulmert D, Lilja H. 2011. A panel of kallikrein marker predicts prostate cancer in a large, population-based cohort followed for 15 years without screening. Cancer Epidemiol Biomarkers Prev 20: 255-261.

Watson PA, Arora VK, Sawyers CL. 2015. Emerging mechanisms of resistance to androgen receptor inhibitors in prostate cancer. Nat Rev Cancer 15: 701-711.

Williamson SR, Zhang S, Yao JL, Huang J, Lopez-Beltran A, Shen S, Osunkoya AO, MacLennan GT, Montironi R, Cheng L. 2011. ERG-TMPRSS2 rearrangement is shared by concurrent prostatic adenocarcinoma and prostatic small cell carcinoma and absent in small cell carcinoma of the urinary bladder: Evidence supporting monoclonal origin. Mod Pathol 24: 1120-1127.

Wise HM, Hermida MA, Leslie NR. 2017. Prostate cancer, PI3K, PTEN and prognosis. Clin Sci (Lond) 131: 197-210.

Wu YM, Su F, Kalyana-Sundaram S, Khazanov N, Ateeq B, Cao X, Lonigro RJ, Vats P, Wang R, Lin SF, et al. 2013. Identification of targetable FGFR gene fusions in diverse cancers. Cancer Discov 3: 636-647.

Wyce A, Degenhardt Y, Bai Y, Le B, Korenchuk S, Crouthame MC, McHugh CF, Vessella R, Creasy CL, Tummino PJ, et al. 2013. Inhibition of BET bromodomain proteins as a therapeutic approach in prostate cancer. Oncotarget 4: 2419-2429.

Yoshimoto M, Cutz JC, Nuin PA, Joshua AM, Bayani J, Evans AJ, Zielenska M, Squire JA. 2006. Interphase FISH analysis of PTEN in histologic sections shows genomic deletions in $68 \%$ of primary prostate cancer and $23 \%$ of high-grade prostatic intra-epithelial neoplasias. Cancer Genet Cytogenet 169: 128-137.

Zheng X, Zhuge J, Bezerra SM, Faraj SF, Munari E, Fallon JT III, Yang XJ, Argani P, Netto GJ, Zhong M. 2014. High frequency of TERT promoter mutation in small cell carcinoma of bladder, but not in small cell carcinoma of other origins. J Hematol Oncol 7: 47. 


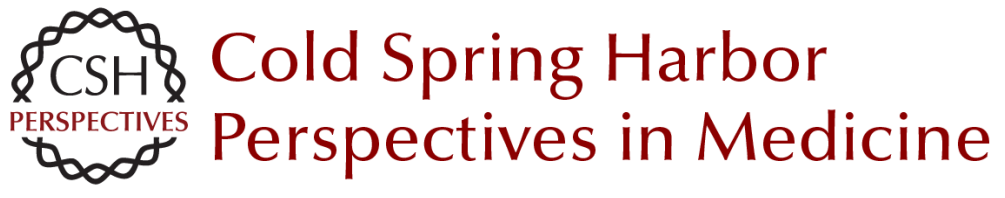

\section{Molecular Biomarkers in the Clinical Management of Prostate Cancer}

Aaron M. Udager and Scott A. Tomlins

Cold Spring Harb Perspect Med 2018; doi: 10.1101/cshperspect.a030601 originally published online January 8, 2018

\section{Subject Collection Prostate Cancer}

Anatomic and Molecular Imaging in Prostate Cancer

Eric T. Miller, Amirali Salmasi and Robert E. Reiter

The Epidemiology of Prostate Cancer Claire H. Pernar, Ericka M. Ebot, Kathryn M. Wilson, et al.

Prostate Stem Cells and Cancer Stem Cells Jia J. Li and Michael M. Shen

Prostate Cancer Epigenetics: From Basic Mechanisms to Clinical Implications Srinivasan Yegnasubramanian, Angelo M. De Marzo and William G. Nelson

\section{The Genomics of Prostate Cancer: A Historic} Perspective Mark A. Rubin and Francesca Demichelis

Neuroendocrine Differentiation in Prostate

Cancer: Emerging Biology, Models, and Therapies Loredana Puca, Panagiotis J. Vlachostergios and Himisha Beltran

DNA Damage Response in Prostate Cancer Matthew J. Schiewer and Karen E. Knudsen

Transcriptional Regulation in Prostate Cancer David P. Labbé and Myles Brown
New Opportunities for Targeting the Androgen Receptor in Prostate Cancer Margaret M. Centenera, Luke A. Selth, Esmaeil Ebrahimie, et al.

Prostate Cancer Research at the Crossroads Michael M. Shen and Mark A. Rubin

Immunotherapy for Prostate Cancer Nicholas J. Venturini and Charles G. Drake

Molecular Pathology of High-Grade Prostatic Intraepithelial Neoplasia: Challenges and Opportunities Levent Trabzonlu, Ibrahim Kulac, Qizhi Zheng, et al.

Metastases in Prostate Cancer Federico La Manna, Sofia Karkampouna, Eugenio Zoni, et al.

Genetically Engineered Mouse Models of Prostate Cancer in the Postgenomic Era Juan M. Arriaga and Cory Abate-Shen

Molecular Biomarkers in the Clinical Management of Prostate Cancer Aaron M. Udager and Scott A. Tomlins

Metabolic Vulnerabilities of Prostate Cancer: Diagnostic and Therapeutic Opportunities Giorgia Zadra and Massimo Loda

For additional articles in this collection, see http://perspectivesinmedicine.cshlp.org/cgi/collection/ 